Original paper

\title{
Chromium- and nickel-rich micas and associated minerals in listvenite from the Muránska Zdychava, Slovakia: products of hydrothermal metasomatic transformation of ultrabasic rock
}

\author{
Štefan FERENC ${ }^{1, *}$, Pavel UHER², Ján SPIŠIAK', Viera ŠIMONOVÁ \\ ${ }^{1}$ Department of Geography and Geology, Faculty of Natural Sciences, Matej Bel University, Tajovského 40, 97401 Banská Bystrica, \\ Slovak Republic; stefan.ferenc@umb.sk \\ 2 Department of Mineralogy and Petrology, Faculty of Natural Sciences, Comenius University, Ilkovičova 6, 84215 Bratislava, \\ Slovak Republic \\ * Corresponding author
}

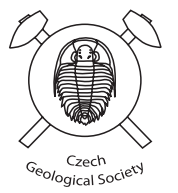

The Cr-Ni-rich micas, Ni-Co sulphide phases and associated minerals occur in a small body of listvenite, an extensively altered serpentinite, in Lower Palaeozoic paragneisses near Muránska Zdychava village in Slovenské Rudohorie Mts. (Veporic Superunit, central Slovakia). The main rock-forming minerals of the listvenite are magnesite, dolomite and a serpentine-group mineral, less frequently calcite, quartz and talc. Accessory minerals of the listvenite include $\mathrm{Cr}-\mathrm{Ni}$ -rich micas, chromite, and $\mathrm{Ni}-\mathrm{Co}-\mathrm{Fe}-(\mathrm{Cu}-\mathrm{Pb})$ sulphide minerals (pyrite, pyrrhotite, pentlandite, millerite, polydymite, violarite, siegenite, gersdorffite, cobaltite, chalcopyrite and galena). The micas from the Muránska Zdychava listvenite (Cr-Ni-rich illite to muscovite and Ni-dominant trioctahedral mica) contain the highest Ni concentrations ever reported in the mica-group minerals (up to $22.8 \mathrm{wt}$. \% $\mathrm{NiO}$ or 1.46 apfu $\mathrm{Ni}$ ). The $\mathrm{Cr}$ concentrations are also relatively high (up to 11.0 wt. $\% \mathrm{Cr}_{2} \mathrm{O}_{3}$ or $0.64 \mathrm{apfu}$ ). Compositional variations in both $\mathrm{Cr}$-Ni-rich mica minerals are characterized by the negative $\mathrm{Cr}$ vs. Ni correlation that indicates a dominant role of $2{ }^{O} \mathrm{M}^{3+}+{ }^{O} \square=3{ }^{O} \mathrm{M}^{2+}$ and ${ }^{O} \mathrm{M}^{3+}+{ }^{T} \mathrm{Al}={ }^{O} \mathrm{M}^{2+}+{ }^{T} \mathrm{Si}$ substitution mechanisms. Chromite is dominated by $\mathrm{Fe}^{2+}(0.82-0.90$ apfu $)$ and $\mathrm{Cr}(1.38-1.79$ apfu).

The listvenite contains $\sim 0.3$ wt. $\% \mathrm{Cr}_{2} \mathrm{O}_{3}$ and $\sim 0.2$ wt. $\% \mathrm{NiO}$. It represents a good example of multistage transformation of an ultrabasic protolith, reflecting variable alteration. The incipient alteration leads to relatively high $\mathrm{SiO}_{2}, \mathrm{MgO}_{\text {, }}$ and $\mathrm{Cr}_{2} \mathrm{O}_{3}$ contents, the latter two typical of ultrabasic rocks. The more advanced alteration stage shows lower $\mathrm{SiO}_{2}$, but higher content of volatiles (c. $35 \mathrm{wt}$. \% of LOI) bound in carbonates and hydrated silicate minerals. Based on geochemical and mineralogical characteristics, the studied listvenite body originated during three principal evolutionary stages: (1) peridotite stage, (2) serpentinization stage, and (3) hydrothermal-metasomatic stage (listvenitization). The listvenite origin was probably connected with Alpine (Late Cretaceous) late-orogenic uplift of the Veporic Superunit crystalline basement and retrograde metamorphism; we assume P-T conditions of the final listvenite stage at $\sim 200 \mathrm{MPa}$ and up to $350^{\circ} \mathrm{C}$. The NE-SW and NW-SE trending fault structures played a key role during the process of listvenitization as they channelized the $\mathrm{CO}_{2}$-rich fluids that transformed the serpentinized peridotite into the carbonate-quartz listvenite.

Keywords: Cr-Ni mineralization, listvenite, Cr-Ni-rich mica, Ni-Co sulphide minerals, Veporic Superunit, Western Carpathians Received: 14 March, 2016; accepted: 26 August, 2016; handling editor: F. Laufek

\section{Introduction}

Term listvenite (listwanite) is generally used for metasomatic rocks, products of strong transformation (carbonatization, silicification) of primary ultrabasic rocks in ophiolite complexes of various ages (e.g., Sazonov 1975; Hansen et al. 2005; Akbulut et al. 2006). Listvenitization of the ultrabasic rocks belongs to mesothermal processes, where the study of fluid inclusions in minerals and other data indicate temperatures of 290 to $340^{\circ} \mathrm{C}$ and pressures of $\sim 100$ to $300 \mathrm{MPa}$ (Halls and Zhao 1995; Plissart et al. 2009; Bagherzadeh et al. 2013). They are commonly connected with gold mineralization or deposits (Dinel et al. 2008; Buckman and Ashley 2010; García et al. 2015 and references therein), whereas massive, tectonically less affected listvenites could be used as gemstones or decorative stones (Simic et al. 2013).

Small listvenite bodies have been described also in ultrabasic rocks of the Western Carpathians, Slovakia. They occur in Palaeozoic (pre-Carboniferous) metamorphic rocks near Jasenie, Nízke Tatry Mts. (Tatric Superunit), Muránska Dlhá Lúka, Slovenské Rudohorie Mts. (Veporic Superunit), in North-Gemeric structural zone (Dobšiná, Mlynky, Rudňany, Vel'ký Folkmár, Košická Belá, Bukovec, Breznička and other localities), and in anchimetamorphic Mesozoic ultramafic rocks near Bôrka in Slovenské Rudohorie Mts., Meliatic Unit (Ivan 1984, 1985; Hovorka et al. 1985).

In this paper, we characterize unusual mineralization in the listvenite body near Muránska Zdychava village 
in the Veporic Superunit, central Slovakia. The carbonate-quartz listvenite contains peculiar mineralization including unique $\mathrm{Cr}-\mathrm{Ni}$-rich micas (with the highest $\mathrm{Ni}$ content in mica-group minerals worldwide), chromite and various $\mathrm{Ni}-\mathrm{Co}-\mathrm{Fe}$ sulphides. The preliminary results, including the mica compositions, were published previously (Uher et al. 2013); however, our contribution deals with a detailed mineral description of the whole association, the rock geochemistry and possible listvenite genesis.

\section{Location and regional geology}

The studied mineralization occurs in $\sim 10 \mathrm{~m}$ large outcrop of listvenitized ultrabasic rocks in close vicinity of the abandoned Horal's gallery in the Rypalová Valley near Muránska Zdychava village (geographic coordinates: $\left.48^{\circ} 45^{\prime} 24^{\prime \prime} \mathrm{N} ; 20^{\circ} 08^{\prime} 01^{\prime \prime} \mathrm{E}\right)$, situated c. $8 \mathrm{~km}$ NNE of Revúca (Slovenské Rudohorie Mts, Central Slovakia).

The occurrence belongs to the Veporic Superunit of the Western Carpathians. The Western Carpathians represent a complex Alpine mountain belt, a part of the Alpine-Carpathian-Balkan Orogen, which resulted from a multi-stage Mesozoic to recent collision between Europe and Africa. The Western Carpathians consist of several nappe superunits, generally with northern vergency. Some superunits (Tatric, Veporic and Gemeric) include tectonic remnants of Early Palaeozoic metamorphic and magmatic basement complexes formed during the Variscan Orogeny, whereby the Veporic Superunit is sandwiched in between the underlying Tatric and overlying Gemeric superunits (e.g., Plašienka et al. 1997 and references therein).

The studied locality belongs to the Kohút Zone of the Veporic Superunit (Fig. 1). It features an allochthonous lithological sequence of Palaeozoic (pre-Carboniferous) rocks, overprinted to micaschists, paragneisses, migmatites, orthogneisses, locally with small occurrences of amphibolites, amphibolitic gneisses and rarely also ultrabasic bodies. This complex is intruded by Variscan (mainly Carboniferous) biotite tonalites, granodiorites to granites (e.g., Klinec 1976; Bezák 1982; Vass et al. 1988; Bezák et al. 1999; Hraško et al. 2005 and references therein). The listvenite body near Muránska Zdychava occurs in non-continuous NE-SW trending zone of amphibolites and small ultrabasic bodies, enclosed in garnetbearing, muscovite-biotite micaschists to paragneisses with distinct mylonitic (phyllonitic) overprint. The listvenite alteration is restricted to ultrabasic members; basic metamorphic rocks (amphibolites and amphibolitic gneisses) were not overprinted. Geological position of the listvenite body near Muránska Zdychava (Fig. 1) indicates pre-Carboniferous age of primary magmatic ultrabasic (peridotite?) protolith.

\section{Methods}

Polished thin sections of listvenite were studied under polarizing optical microscope (Nikon Eclipse LV 100 POL, Matej Bel University, Banská Bystrica) in transmitted and reflected light. Chemical composition of minerals was determined by the CAMECA SX100 electron microprobe in WDS mode (State Geological Institute of Dionýz Štúr, Bratislava). Acceleration voltage of $15 \mathrm{kV}$ and probe current of $20 \mathrm{nA}$ for chromite, silicate and carbonate minerals, $15 \mathrm{kV}$ and $10 \mathrm{nA}$ for micas, and $25 \mathrm{kV}$ and 10 $\mathrm{nA}$ for sulphide minerals were used during the electronmicroprobe measurements. The following standards and spectral lines were used: wollastonite $\left(\mathrm{Si} \mathrm{K}, \mathrm{Ca} \mathrm{K}_{\alpha}\right)$, $\mathrm{TiO}_{2}\left(\mathrm{Ti} \mathrm{K}_{\alpha}\right), \mathrm{Al}_{2} \mathrm{O}_{3}\left(\mathrm{Al} \mathrm{K} \mathrm{K}_{\alpha}\right)$, native $\mathrm{V}\left(\mathrm{V} \mathrm{K}_{\alpha}\right)$, native $\mathrm{Cr}$ $\left(\mathrm{Cr} \mathrm{K}_{\alpha}\right)$, fayalite $\left(\mathrm{Fe} \mathrm{K} \mathrm{K}_{\alpha}\right.$ ), rhodonite $\left(\mathrm{Mn} \mathrm{K}_{\alpha}\right)$, willemite and $\mathrm{ZnS}\left(\mathrm{Zn} \mathrm{K}_{\alpha}\right)$, forsterite $\left(\mathrm{Mg} \mathrm{K}_{\alpha}\right), \mathrm{SrTiO}_{3}\left(\mathrm{Sr} \mathrm{K}_{\alpha}\right)$, pyrite $\left(\mathrm{Fe} \mathrm{K} \alpha, \mathrm{S} \mathrm{K}_{\alpha}\right)$, native $\mathrm{Cu}(\mathrm{Cu} \mathrm{K})$, native $\mathrm{Au}(\mathrm{Au}$ $\mathrm{L}_{\alpha}$ ), native $\mathrm{Ni}\left(\mathrm{Ni} \mathrm{K}_{\alpha}\right)$, native Co $\left(\mathrm{Co} \mathrm{K}_{\alpha}\right)$, GaAs $\left(\mathrm{As} \mathrm{L}_{\alpha}\right.$, $\operatorname{InSb}\left(\mathrm{Sb} \mathrm{L}_{\beta}\right), \mathrm{Bi}_{2} \mathrm{Se}_{3}\left(\mathrm{Se} \mathrm{L}_{\beta}\right)$, and $\mathrm{PbS}\left(\mathrm{Pb} \mathrm{M}_{\alpha}\right)$. The beam diameter of 2 to $20 \mu \mathrm{m}$ was used with respect to the size and character of measured mineral. Detection limits for measured elements attained 0.02 to 0.1 wt. $\%$, depending on concentration. The raw measurements were corrected by the PAP procedure (Pouchou and Pichoir 1985).

Whole-rock chemical composition of listvenite was analysed in the ACME Analytical Laboratories Ltd., Vancouver, Canada (http://www.acmelab.com). Samples were dissolved in Aqua Regia (AQ200). The major-element oxides were determined by the Inductively Coupled Plasma-Optical Emission Spectrometry (ICP-OES; LF300), trace elements Inductively Coupled Plasma-Mass Spectrometry (ICP-MS; LF100, LF100-EXT) analyses; C and $\mathrm{S}$ have been determined by the LECO induction furnace (TC003). The loss on ignition (LOI) was determined by sample annealing at $1000^{\circ} \mathrm{C}$ during 2 hours.

\section{Results}

\subsection{Zoning of the listvenite body}

The listvenite outcrop shows mineral zoning and following principal petrographic types (differing

Fig. 1a - Simplified geological sketch of central part of the Slovenské Rudohorie Mts. (Slavkay et al. 2004, adapted) with the listvenite occurrence also marked. b - Detailed geological map of the Muránska Zdychava listvenite body and surrounding area (according to Hraško et al. 2005). 


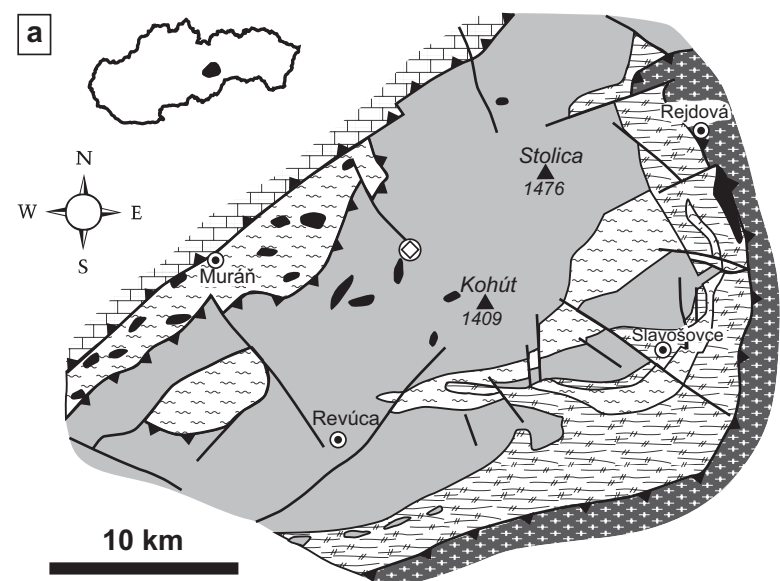

Silicicum Unit: limestones, dolomites (Triassic to Jurassic)

Gemericum Unit: clastic sediments, limestones, magnesites,

$++$ lydites, phyllites and basic volcanic rocks (Devonian-Permian)

\section{Veporicum Unit}

Revúca Group: metamorphosed and unmetamorphosed clastic sedimentary rocks, volcanic rocks (Upper Paleozoic)

Phyllites, mica schists, ortho- and paragneisses (Lower Palaeozoic?)

Metabasites and ultrabasic rocks (Lower Palaeozoic?)

Undifferentiated granitoids, locally migmatitised (Carboniferous)

Thrust planes

$\approx$ Faults

$\otimes$ Listvenite occurrence

b

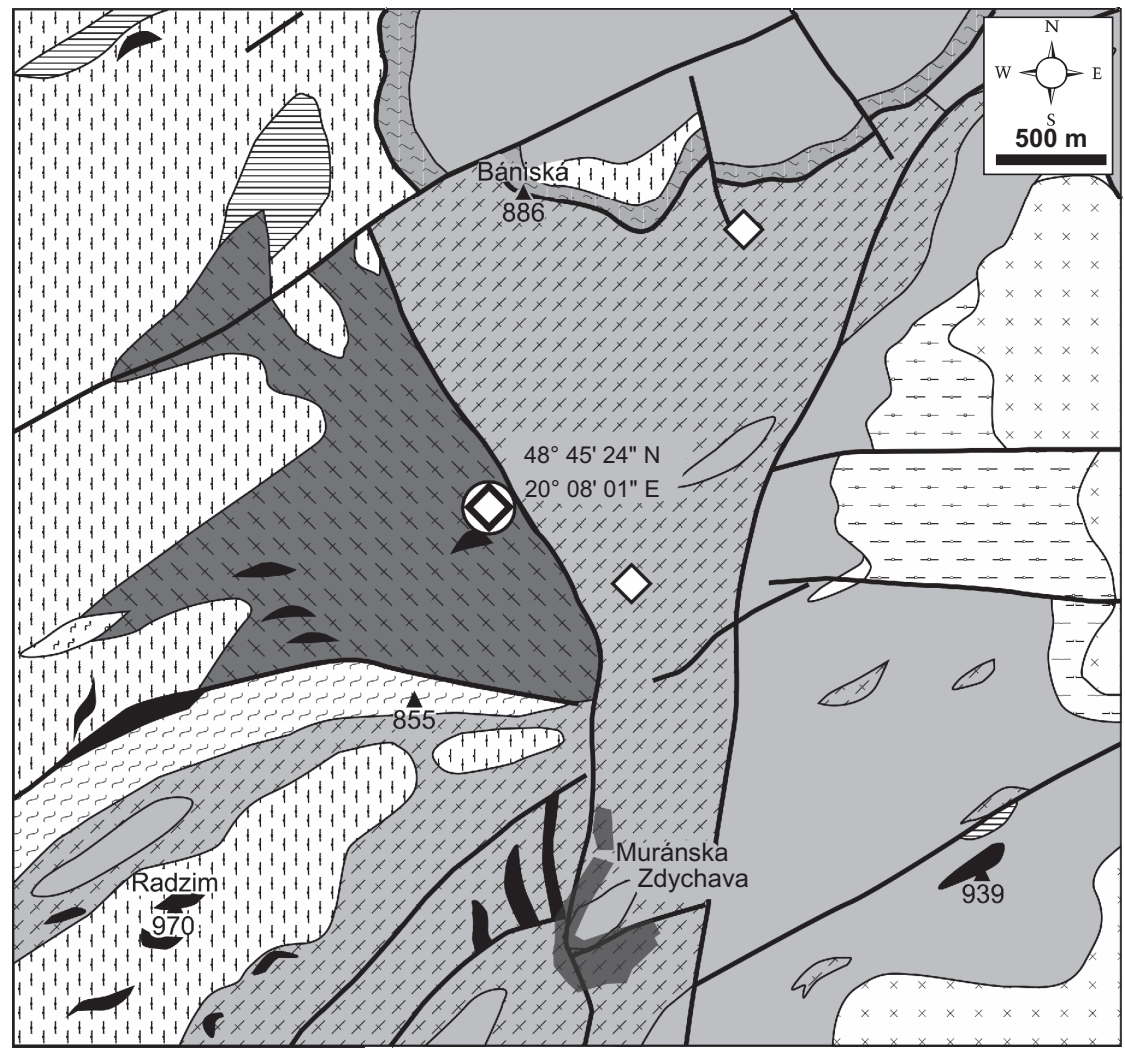

\section{Early Palaeozoic?}

Hydrothermally altered diaphtorites and phyllonites

Garnet-chlorite-muscovite schists Biotite paragneisses, locally migmatitised

Muscovite-biotite paragneisses, locally diaphtorised

Migmatites and migmatitised gneisses

B_- Blastoporphyric orthogneisses

Feldspar orthogneisses (Muráň Type), migmatites

Amphibolites, amphibolitic

gneisses

\section{Carboniferous}

Porphyritic, biotite granites, granodiorites (Kohút Type)

Granitoids with orthogneiss

bodies

\footnotetext{
Tectonic structures

(8) Listvenite occurrence

$\checkmark$ Alpine Fe carbonate and quartz-sulphidic mineralization occurrences
} 
mainly in the carbonate contents) in a $\sim 10 \mathrm{~m}$ profile from east to west:

1) L1 type is relatively compact listvenite with massive structure and greyish green to pale green colour with irregular deep green domains. Locally the rock is cut by veinlets (up to $5 \mathrm{~mm}$ thick) of coarse- grained white calcite and yellowish fine- grained dolomite.

2) L2 type corresponds to yellowish-green listvenite similar to L1 type, but with stronger dolomitization.

3) L3 type represents grey listvenite with greenish tint and yellowish irregular veinlets/aggregates of dolomite. The rock displays slight metamorphic foliation.

\subsection{Listvenite mineralogy}

\subsubsection{Main rock-forming minerals}

The rock-forming minerals of the all three listvenite types are mainly magnesite, dolomite and serpentine-group minerals, less frequently calcite, quartz, talc, and $\mathrm{Cr}-\mathrm{Ni}$ rich members of the mica group.

Magnesite is the most common mineral of the listvenite, especially in the L1 and L2 types. On the basis of textural relationships and chemical composition, magnesite occurs in two generations. Magnesite I forms relatively coarse-grained aggregates; the size of individual grains attains $0.5 \mathrm{~mm}$ (Fig. 2a-b). Younger magnesite II fills veinlets (up to $0.1 \mathrm{~mm}$ thick) in magnesite I aggregates (Fig. 2b). Magnesite II shows higher concentration of $\mathrm{Mg}$ and lower Fe content compared to magnesite I (Tab. 1, Fig. 3).

Dolomite also forms two compositional types: dolomite $\mathrm{I}$ is slightly depleted in $\mathrm{Mg} /(\mathrm{Mg}+\mathrm{Ca})$ (0.38-0.40), whereas dolomite II shows higher $\mathrm{Mg} /(\mathrm{Mg}+\mathrm{Ca})$ ratio (0.47-0.48; Tab. 1, Fig. 3). Both dolomite types were probably cogenetic (Fig. 2a) and their irregular aggregates and veinlets cut the magnesite I and II (Fig. 2b).

Calcite is the youngest carbonate mineral; it forms irregular crack-fillings $(\leq 5 \mathrm{~mm}$ thick) in magnesite I and II, dolomite I and II, Cr-Ni-rich micas and quartz. Chemical composition of the calcite is close to the ideal formula.
Quartz forms irregular aggregates, up to $0.2 \mathrm{~mm}$ across, or narrow veinlets in magnesite I and II (Fig. 2ab). However, it is older than dolomite and $\mathrm{Cr}-\mathrm{Ni}$-rich micas (Fig. 2c).

Minerals of the serpentine group are common in all listvenite types, especially in the L3, where they locally make up a dominant part of the rock. The serpentine-group minerals (most probably antigorite) form aggregates of lamellar crystals, 50 to $100 \mu \mathrm{m}$ in size or independent crystals in magnesite. They overgrew aggregates of magnesite I and talc (Fig. 2d). Chemical composition of the serpentine minerals (Tab. 2) shows a distinct enrichment in $\mathrm{Fe}(\sim 7$ wt. \% $\mathrm{FeO} ; \sim 0.27 a p f u$ ), relatively low $\mathrm{Al}$ content (0.6 to 1.3 wt. $\% \mathrm{Al}_{2} \mathrm{O}_{3} ; 0.03-0.08 \mathrm{apfu}$ ), as well as elevated concentrations of $\mathrm{Cr}$ (0.3 to 0.9 wt. $\% \mathrm{Cr}_{2} \mathrm{O}_{3} ; 0.01-0.03$ $a p f u)$ and $\mathrm{Ni}(\sim 0.1$ wt. \% NiO; $0.005 a p f u)$.

Talc forms irregular aggregates (up to $0.1 \mathrm{~mm}$ ) in association with the serpentine-group minerals (Fig. 2d). Composition of talc (Tab. 2) shows slightly increased content of $\mathrm{Fe}(\sim 2.4$ wt. \% FeO; 0.26 apfu) with a negligible admixture of $\mathrm{Cr}\left(\sim 0.1\right.$ wt. $\% \mathrm{Cr}_{2} \mathrm{O}_{3} ; 0.009$ apfu $)$ and $\mathrm{Ni}(\sim 0.2$ wt. $\% \mathrm{NiO} ; 0.025$ apfu).

Tab. 1 Representative compositions of magnesite and dolomite from the Muránska Zdychava listvenite

\begin{tabular}{|c|c|c|c|c|c|c|c|c|c|}
\hline \multicolumn{10}{|l|}{ wt. \% } \\
\hline Anal. \# & $\mathrm{MgO}$ & $\mathrm{CaO}$ & $\mathrm{FeO}$ & $\mathrm{MnO}$ & $\mathrm{SrO}$ & Total & \multicolumn{3}{|l|}{ Mineral } \\
\hline 1 & 42.16 & 0.32 & 8.99 & 0.60 & 0.01 & 52.08 & \multicolumn{3}{|c|}{ magnesite I } \\
\hline 2 & 42.88 & 0.18 & 9.89 & 0.33 & 0.00 & 53.28 & \multicolumn{3}{|c|}{ magnesite I } \\
\hline 3 & 42.62 & 0.43 & 8.95 & 0.59 & 0.00 & 52.59 & \multicolumn{3}{|c|}{ magnesite I } \\
\hline 4 & 45.08 & 0.12 & 5.07 & 1.24 & 0.00 & 51.50 & \multicolumn{3}{|c|}{ magnesite II } \\
\hline 5 & 46.75 & 0.36 & 3.83 & 0.01 & 0.04 & 50.99 & \multicolumn{3}{|c|}{ magnesite II } \\
\hline 6 & 45.16 & 0.35 & 6.05 & 0.27 & 0.00 & 51.83 & \multicolumn{3}{|c|}{ magnesite II } \\
\hline 7 & 45.70 & 0.49 & 4.53 & 0.02 & 0.00 & 50.75 & \multicolumn{3}{|c|}{ magnesite II } \\
\hline 8 & 45.27 & 0.66 & 4.82 & 0.04 & 0.00 & 50.80 & \multicolumn{3}{|c|}{ magnesite II } \\
\hline 9 & 15.73 & 32.81 & 3.90 & 0.08 & 0.04 & 52.56 & \multicolumn{3}{|c|}{ dolomite I } \\
\hline 10 & 14.46 & 32.80 & 5.34 & 0.17 & 0.03 & 52.79 & \multicolumn{3}{|l|}{ dolomite I } \\
\hline 11 & 14.49 & 32.77 & 5.03 & 0.12 & 0.05 & 52.45 & \multicolumn{3}{|l|}{ dolomite I } \\
\hline 12 & 18.87 & 28.72 & 4.40 & 0.16 & 0.07 & 52.22 & \multicolumn{3}{|c|}{ dolomite II } \\
\hline 13 & 18.79 & 29.09 & 4.66 & 0.16 & 0.05 & 52.75 & \multicolumn{3}{|c|}{ dolomite II } \\
\hline \multicolumn{10}{|l|}{ at. $\%$} \\
\hline Anal. \# & $\mathrm{Mg}$ & $\mathrm{Ca}$ & $\mathrm{Fe}$ & $\mathrm{Mn}$ & $\mathrm{Sr}$ & $\mathrm{O}$ & Mineral & $\mathrm{Mg} /(\mathrm{Mg}+\mathrm{Ca})$ & $\mathrm{Fe} /(\mathrm{Mg}+\mathrm{Fe})$ \\
\hline 1 & 44.11 & 0.24 & 5.28 & 0.35 & 0.00 & 50.01 & Mgs I & 0.995 & 0.893 \\
\hline 2 & 43.98 & 0.14 & 5.69 & 0.19 & 0.00 & 50.01 & Mgs I & 0.997 & 0.885 \\
\hline 3 & 44.13 & 0.32 & 5.20 & 0.35 & 0.00 & 50.01 & Mgs I & 0.993 & 0.895 \\
\hline 4 & 46.27 & 0.09 & 2.92 & 0.72 & 0.00 & 50.01 & Mgs II & 0.998 & 0.941 \\
\hline 5 & 47.52 & 0.27 & 2.18 & 0.01 & 0.01 & 50.01 & Mgs II & 0.994 & 0.956 \\
\hline 6 & 46.12 & 0.25 & 3.47 & 0.16 & 0.00 & 50.01 & Mgs II & 0.995 & 0.930 \\
\hline 7 & 47.00 & 0.36 & 2.62 & 0.01 & 0.00 & 50.01 & Mgs II & 0.992 & 0.947 \\
\hline 8 & 46.69 & 0.49 & 2.79 & 0.02 & 0.00 & 50.01 & Mgs II & 0.990 & 0.944 \\
\hline 9 & 18.92 & 28.37 & 2.63 & 0.06 & 0.02 & 50.00 & Dol I & 0.400 & 0.878 \\
\hline 10 & 17.57 & 28.66 & 3.64 & 0.11 & 0.01 & 50.00 & Dol I & 0.380 & 0.828 \\
\hline 11 & 17.69 & 28.76 & 3.45 & 0.08 & 0.02 & 50.00 & Dol I & 0.381 & 0.837 \\
\hline 12 & 22.41 & 24.51 & 2.93 & 0.11 & 0.03 & 50.00 & Dol II & 0.478 & 0.884 \\
\hline 13 & 22.14 & 24.64 & 3.08 & 0.10 & 0.02 & 50.00 & Dol II & 0.473 & 0.878 \\
\hline
\end{tabular}



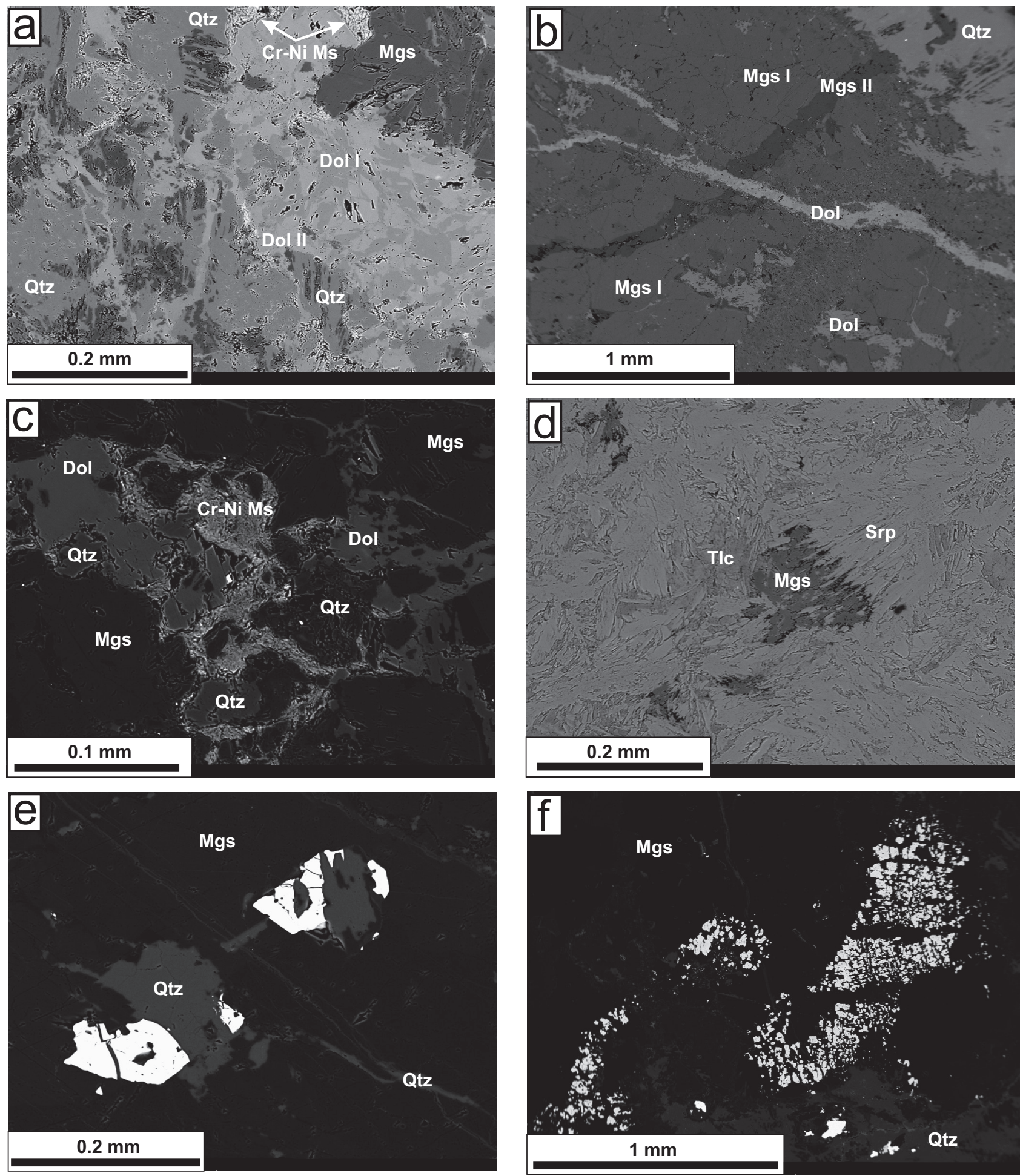

Fig. 2 Back-scattered electron images (BSE) of mineral associations in the Muránska Zdychava listvenite. a - Quartz (Qtz) and magnesite (Mgs) replaced by dolomite (Dol I, Dol II). The carbonates are replaced by $\mathrm{Cr}-\mathrm{Ni}$ muscovite (Cr-Ni Ms) along the mineral rims. Quartz also overgrows relicts of magnesite I. b - Both of magnesite generations (Mgs) are cut by dolomite veinlets (Dol) and replaced by quartz aggregates (Qtz). $\mathbf{c}-$ Irregular aggregates of magnesite (Mgs), dolomite (Dol) and quartz are replaced by $\mathrm{Cr}-\mathrm{Ni}$-rich muscovite (Cr-Ni Ms). $\mathbf{d}-\mathrm{Magnesite}$ (Mgs) relicts are overgrown and replaced by serpentine-group minerals (Srp), less frequently by talc (Tlc). Locally, talc forms intergrowths with serpentine-group minerals. e - Quartz (Qtz) fills tiny veinlets in magnesite (Mgs) and it replaces chromite grains (white). f - Chess-board breakdown of chromite (white) in magnesite (Mgs). Quartz (Qtz) forms irregular aggregates and veinlets in magnesite. Irregular white grains at bottom of the picture are sulphides. 


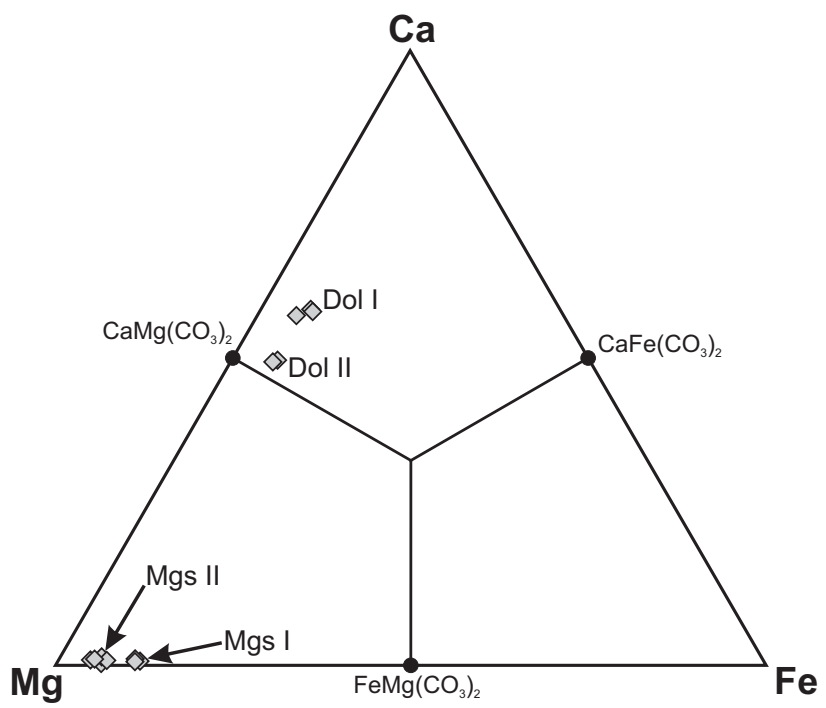

Fig. 3 Composition of magnesite and dolomite from Muránska Zdychava listvenite in ternary $\mathrm{Mg}-\mathrm{Ca}-\mathrm{Fe}$ diagram (at. \%).

\subsection{2. $\mathrm{Cr}-\mathrm{Ni}$-rich micas}

The $\mathrm{Cr}-\mathrm{Ni}$-rich members of the mica group are characteristic minerals of the listvenite from Muránska Zdychava. They cause a green colour, especially of the L1 and L2 listvenite types. The micas form irregular, usually 20 to

Tab. 2 Representative compositions of serpentine-group minerals (analyses 1 to 4 ) and talc (anal. 5) from the Muránska Zdychava listvenite

\begin{tabular}{|c|c|c|c|c|c|}
\hline \multirow{2}{*}{$\begin{array}{l}\text { Mineral } \\
\text { Anal. \# }\end{array}$} & \multicolumn{4}{|c|}{ Minerals of the serpentine group } & \multirow{2}{*}{$\begin{array}{c}\text { Talc } \\
5\end{array}$} \\
\hline & 1 & 2 & 3 & 4 & \\
\hline $\mathrm{SiO}_{2}$ & 44.34 & 43.83 & 43.32 & 42.69 & 61.94 \\
\hline $\mathrm{Al}_{2} \mathrm{O}_{3}$ & 0.60 & 0.89 & 0.75 & 1.34 & 0.00 \\
\hline $\mathrm{Cr}_{2} \mathrm{O}_{3}$ & 0.26 & 0.47 & 0.44 & 0.91 & 0.09 \\
\hline $\mathrm{FeO}$ & 7.00 & 6.72 & 7.19 & 6.97 & 2.35 \\
\hline $\mathrm{MgO}$ & 35.92 & 35.73 & 35.87 & 35.90 & 28.90 \\
\hline $\mathrm{NiO}$ & 0.13 & 0.12 & 0.11 & 0.12 & 0.24 \\
\hline $\mathrm{H}_{2} \mathrm{O}$ calc. & 12.68 & 12.68 & 12.64 & 12.62 & 4.70 \\
\hline Total & 100.94 & 100.44 & 100.32 & 100.55 & 98.23 \\
\hline \multicolumn{6}{|c|}{ empirical formulae } \\
\hline $\mathrm{Si}$ & 2.075 & 2.062 & 2.048 & 2.016 & 8.052 \\
\hline $\mathrm{Al}$ & 0.033 & 0.050 & 0.042 & 0.075 & \\
\hline $\mathrm{Cr}$ & 0.010 & 0.018 & 0.016 & 0.034 & 0.009 \\
\hline $\mathrm{Fe}$ & 0.274 & 0.264 & 0.284 & 0.275 & 0.256 \\
\hline $\mathrm{Mg}$ & 2.506 & 2.506 & 2.528 & 2.526 & 5.601 \\
\hline $\mathrm{Ni}$ & 0.005 & 0.005 & 0.004 & 0.005 & 0.025 \\
\hline Sum $O$ & 2.828 & 2.842 & 2.874 & 2.915 & 5.891 \\
\hline $\mathrm{OH}$ & 4.000 & 4.000 & 4.000 & 4.000 & 4.000 \\
\hline $\mathrm{O}$ & 5.000 & 5.000 & 5.000 & 5.000 & 20.000 \\
\hline Sum of anions & 9.000 & 9.000 & 9.000 & 9.000 & 24.000 \\
\hline
\end{tabular}

The crystallochemical formulae are calculated on the basis of 5 oxygen (analyses 1-4) and 20 oxygen atoms (analysis 5). The $\mathrm{H}_{2} \mathrm{O}$ content was estimaed in respect to stoichiometry of the ideal formulae
$100 \mu \mathrm{m}$ large aggregates and veinlets of very fine platy crystals (up to $5 \mu \mathrm{m}$ in size) in microcracks of magnesite, dolomite and quartz (Fig. 2c).

Chemical composition of the micas (Tab. 3) shows two compositional members: $\mathrm{Cr}-\mathrm{Ni}$-rich illite to muscovite and $\mathrm{Cr}-\mathrm{Ni}$-rich trioctahedral mica, both being characterized by unusually high contents of $\mathrm{Cr}^{3+}$ and $\mathrm{Ni}^{2+}$ in octahedral $(O)$ site. The muscovite (Tab. 3, anal. 1 to 6 ) attains 7.6 to 11.0 wt. $\% \mathrm{Cr}_{2} \mathrm{O}_{3}(0.44-0.64$ apfu $\mathrm{Cr})$ and 2.4 to 14.0 wt. $\% \mathrm{NiO}(0.13-0.84$ apfu $\mathrm{Ni})$. Octahedral $\mathrm{Al}^{3+}$ is the dominant cation in the $O$ site $(0.87$ to $1.19 \mathrm{apfu})$, whereas contents of octahedral $\mathrm{Mg}$ and $\mathrm{Fe}$ (assumed as $\mathrm{Fe}^{2+}$ ) achieve only $0.15-0.23$ and $0.03-0.15 \mathrm{apfu}$, respectively. Sum of trivalent octahedral cations $\left({ }^{\circ} \mathrm{M}^{3+}=1.34\right.$ to $1.71)$ is always higher than sum of the divalent ones $\left({ }^{\circ} \mathrm{M}^{2+}\right.$ $=0.44$ to 1.07$)$, whereas amount of interlayer cations $(\mathrm{K}$, $\mathrm{Na}, \mathrm{Ca})$ attains only 0.57 to 0.73 apfu $(0.55-0.69$ apfu $\mathrm{K}$ ), possibly due to the presence of $\mathrm{H}_{3} \mathrm{O}^{+}$cation and/or interlayer vacancy. Therefore, the mica could be classified as dioctahedral, $\mathrm{Cr}-\mathrm{Ni}$-rich illite to muscovite.

Two analyses (Tab. 3, anal. 7 and 8) show the lowest $\mathrm{Cr}$ but the highest $\mathrm{Ni}$ contents: 5.7 to $6.5 \mathrm{wt}$ \% $\mathrm{Cr}_{2} \mathrm{O}_{3}(0.36-0.40$ apfu $\mathrm{Cr})$ and 19.4 to 22.8 wt. $\% \mathrm{NiO}$ $(1.21-1.46$ apfu $\mathrm{Ni})$, respectively. On the contrary, these two compositions reveal the lowest contents of octahedral $\mathrm{Al}(0.55$ to $0.69 a p f u)$ and sum of interlayer cations (0.47 to $0.52 a p f u$; of this $0.46-0.50$ apfu $\mathrm{K})$. Nickel is a dominant divalent octahedral cation and ${ }^{\circ} \mathrm{M}^{2+}>{ }^{o} \mathrm{M}^{3+}$, whereby the sum of all octahedral cations is over 2.5 (2.54 to 2.67; Tab. 3, anal. 7 and 8). Consequently, they belong to $\mathrm{Ni}$-dominant and $\left(\mathrm{H}_{3} \mathrm{O}\right)$-bearing or interlayerdeficient trioctahedral mica, close to the following formulae: $\left[\mathrm{K}_{0.5}\left(\mathrm{H}_{3} \mathrm{O}\right)_{0.5}\right]\left[\mathrm{Ni}_{1.5}(\mathrm{Al}, \mathrm{Cr})_{1} \square_{0.5}\right]\left(\mathrm{AlSi}_{3}\right) \mathrm{O}_{10}(\mathrm{OH})_{2}$ or $\left[\mathrm{K}_{0.5} \square_{0.5}\right]\left[\mathrm{Ni}_{1.5}(\mathrm{Al}, \mathrm{Cr})_{1} \square_{0.5}\right]\left(\mathrm{Al}_{0.5} \mathrm{Si}_{3.5}\right) \mathrm{O}_{10}(\mathrm{OH})_{2}$.

Compositional variations in both $\mathrm{Cr}$-Ni-rich mica minerals indicate a dominant role for the muscoviteannite/phlogopite and muscovite-(alumino)celadonite (Tschermak-type) substitution mechanisms: $2^{\circ} \mathrm{M}^{3+}+{ }^{\circ} \square=$ $3^{O} \mathrm{M}^{2+}$ and ${ }^{O} \mathrm{M}^{3+}+{ }^{T} \mathrm{Al}={ }^{O} \mathrm{M}^{2+}+{ }^{T} \mathrm{Si}$, respectively (Fig. 4a). Chromium negatively correlates with nickel (Fig. 4b), consequently both $2^{\circ} \mathrm{Cr}^{3+}+{ }^{O} \square=3^{\circ} \mathrm{Ni}^{2+}$ and ${ }^{O} \mathrm{Cr}+{ }^{T} \mathrm{Al}=$ ${ }^{\circ} \mathrm{Ni}+{ }^{T} \mathrm{Si}$ mechanisms possibly explain the incorporation of the $\mathrm{Cr}^{3+}$ and $\mathrm{Ni}^{2+}$ cations into the mica structure.

\subsubsection{Chromite}

Chromite is a widespread accessory mineral of the listvenite; it occurs as euhedral to subhedral, partly corroded crystals (usually 10 to $150 \mu \mathrm{m}$, exceptionally up to 1.2 $\mathrm{mm}$ in size) enclosed in magnesite I and II. Locally, chromite is cut by quartz veinlets (Fig. 2e). Moreover, some larger chromite crystals show "chess-board" breakdown patterns and partial replacement by magnesite (Fig. 2f). Chromite is dominated by $\mathrm{Fe}^{2+}$ (0.82 to 0.90 apfu) and 
Cr (1.38 to 1.79 apfu) (Tab. 4, Fig. 5a-b); concentrations of $\mathrm{Mg}(0.05$ to 0.12 apfu $), \mathrm{Fe}^{3+}$ (0.05 to 0.31 apfu) and $\mathrm{Al}(0.02$ to $0.18 \mathrm{apfu}$ ) are relatively low. Magnesium reveals a strong negative correlation with $\mathrm{Fe}^{2+}$ $(\mathrm{r}=-0.98)$. Contents of $\mathrm{Zn}$, $\mathrm{Mn}, \mathrm{Ti}$ and $\mathrm{V}$ are subordinate $(\leq 0.05 \mathrm{apfu})$.

\subsubsection{Sulphide minerals}

The sulphide and sulphoarsenide phases are characteristic accessory minerals of the Muránska Zdychava listvenite (Fig. 6). The $\mathrm{Ni}-\mathrm{Co}-\mathrm{Fe}-(\mathrm{Cu}-$ $\mathrm{Pb}$ ) sulphide and sulphoarsenide minerals include pyrite, millerite, pyrrhotite, gersdorffite, cobaltite, polydymite, violarite, siegenite, pentlandite, chalcopyrite, and galena (Fig. 7a). Generally, they form scattered isometric grains (up to $0.2 \mathrm{~mm}$ ) or veinlets ( $\sim 1$ to $0.1 \mathrm{~mm})$ of discrete mineral (e.g., pyrite, millerite and pyrrhotite) or aggregates of several phases (e.g., millerite + pyrite + gersdorffite), usually in magnesite I. The
Tab. 3 Representative compositions of Cr-Ni-rich micas from the Muránska Zdychava listvenite

\begin{tabular}{|c|c|c|c|c|c|c|c|c|}
\hline Anal. \# & 1 & 2 & 3 & 4 & 5 & 6 & 7 & 8 \\
\hline $\mathrm{SiO}_{2}$ & 46.05 & 46.55 & 48.35 & 46.71 & 45.74 & 44.07 & 42.56 & 40.94 \\
\hline $\mathrm{TiO}_{2}$ & 0.00 & 0.00 & 0.05 & 0.04 & 0.00 & 0.00 & 0.00 & 0.03 \\
\hline $\mathrm{Al}_{2} \mathrm{O}_{3}$ & 22.87 & 21.94 & 20.36 & 18.82 & 18.61 & 18.22 & 15.05 & 13.72 \\
\hline $\mathrm{Cr}_{2} \mathrm{O}_{3}$ & 10.20 & 11.05 & 9.94 & 9.47 & 7.63 & 7.90 & 6.54 & 5.71 \\
\hline $\mathrm{FeO}$ & 2.17 & 1.11 & 0.67 & 1.21 & 0.82 & 1.00 & 1.07 & 0.99 \\
\hline $\mathrm{MnO}$ & 0.03 & 0.05 & 0.10 & 0.06 & 0.08 & 0.06 & 0.09 & 0.13 \\
\hline $\mathrm{NiO}$ & 2.36 & 4.01 & 8.06 & 10.25 & 12.59 & 13.97 & 19.40 & 22.81 \\
\hline $\mathrm{MgO}$ & 1.77 & 1.46 & 1.77 & 1.44 & 1.48 & 1.47 & 1.42 & 1.86 \\
\hline $\mathrm{CaO}$ & 0.16 & 0.13 & 0.19 & 0.10 & 0.11 & 0.11 & 0.11 & 0.09 \\
\hline $\mathrm{Na}_{2} \mathrm{O}$ & 0.21 & 0.06 & 0.10 & 0.00 & 0.53 & 0.09 & 0.05 & 0.00 \\
\hline $\mathrm{K}_{2} \mathrm{O}$ & 7.60 & 7.78 & 6.81 & 6.46 & 6.27 & 5.76 & 5.02 & 4.57 \\
\hline $\mathrm{H}_{2} \mathrm{O}$ calc. & 4.26 & 4.27 & 4.33 & 4.19 & 4.12 & 4.03 & 3.86 & 3.76 \\
\hline Total & 97.68 & 98.41 & 100.73 & 98.75 & 97.98 & 96.68 & 95.17 & 94.61 \\
\hline \multicolumn{9}{|c|}{ Formulae based on $10 \mathrm{O}$ and $2(\mathrm{OH})$ anions } \\
\hline $\mathrm{Si}$ & 3.242 & 3.271 & 3.346 & 3.344 & 3.329 & 3.277 & 3.308 & 3.263 \\
\hline Al $T$ & 0.758 & 0.729 & 0.654 & 0.656 & 0.671 & 0.723 & 0.692 & 0.737 \\
\hline Sum $T$ & 4.000 & 4.000 & 4.000 & 4.000 & 4.000 & 4.000 & 4.000 & 4.000 \\
\hline $\mathrm{Ti}$ & 0.000 & 0.000 & 0.003 & 0.002 & 0.000 & 0.000 & 0.000 & 0.002 \\
\hline Al $O$ & 1.140 & 1.088 & 1.006 & 0.932 & 0.925 & 0.874 & 0.686 & 0.552 \\
\hline $\mathrm{Cr}$ & 0.568 & 0.614 & 0.544 & 0.536 & 0.439 & 0.465 & 0.402 & 0.360 \\
\hline $\mathrm{Fe}$ & 0.128 & 0.065 & 0.039 & 0.072 & 0.050 & 0.062 & 0.070 & 0.066 \\
\hline $\mathrm{Mn}$ & 0.002 & 0.003 & 0.006 & 0.004 & 0.005 & 0.004 & 0.006 & 0.009 \\
\hline $\mathrm{Ni}$ & 0.134 & 0.227 & 0.449 & 0.590 & 0.737 & 0.836 & 1.213 & 1.462 \\
\hline $\mathrm{Mg}$ & 0.186 & 0.153 & 0.183 & 0.154 & 0.161 & 0.163 & 0.165 & 0.221 \\
\hline Sum $O$ & 2.158 & 2.150 & 2.230 & 2.290 & 2.317 & 2.404 & 2.542 & 2.672 \\
\hline $\mathrm{Ca}$ & 0.012 & 0.010 & 0.014 & 0.008 & 0.009 & 0.009 & 0.009 & 0.008 \\
\hline $\mathrm{Na}$ & 0.029 & 0.008 & 0.013 & 0.000 & 0.075 & 0.013 & 0.008 & 0.000 \\
\hline $\mathrm{K}$ & 0.683 & 0.698 & 0.601 & 0.590 & 0.582 & 0.546 & 0.498 & 0.465 \\
\hline Sum $I$ & 0.724 & 0.716 & 0.628 & 0.598 & 0.666 & 0.568 & 0.515 & 0.473 \\
\hline Al total & 1.898 & 1.817 & 1.660 & 1.588 & 1.596 & 1.597 & 1.378 & 1.289 \\
\hline Sum $\mathrm{M}^{3+} O$ & 1.708 & 1.702 & 1.550 & 1.468 & 1.364 & 1.339 & 1.088 & 0.912 \\
\hline Sum $\mathrm{M}^{2+} O$ & 0.450 & 0.448 & 0.677 & 0.820 & 0.953 & 1.065 & 1.454 & 1.758 \\
\hline
\end{tabular}
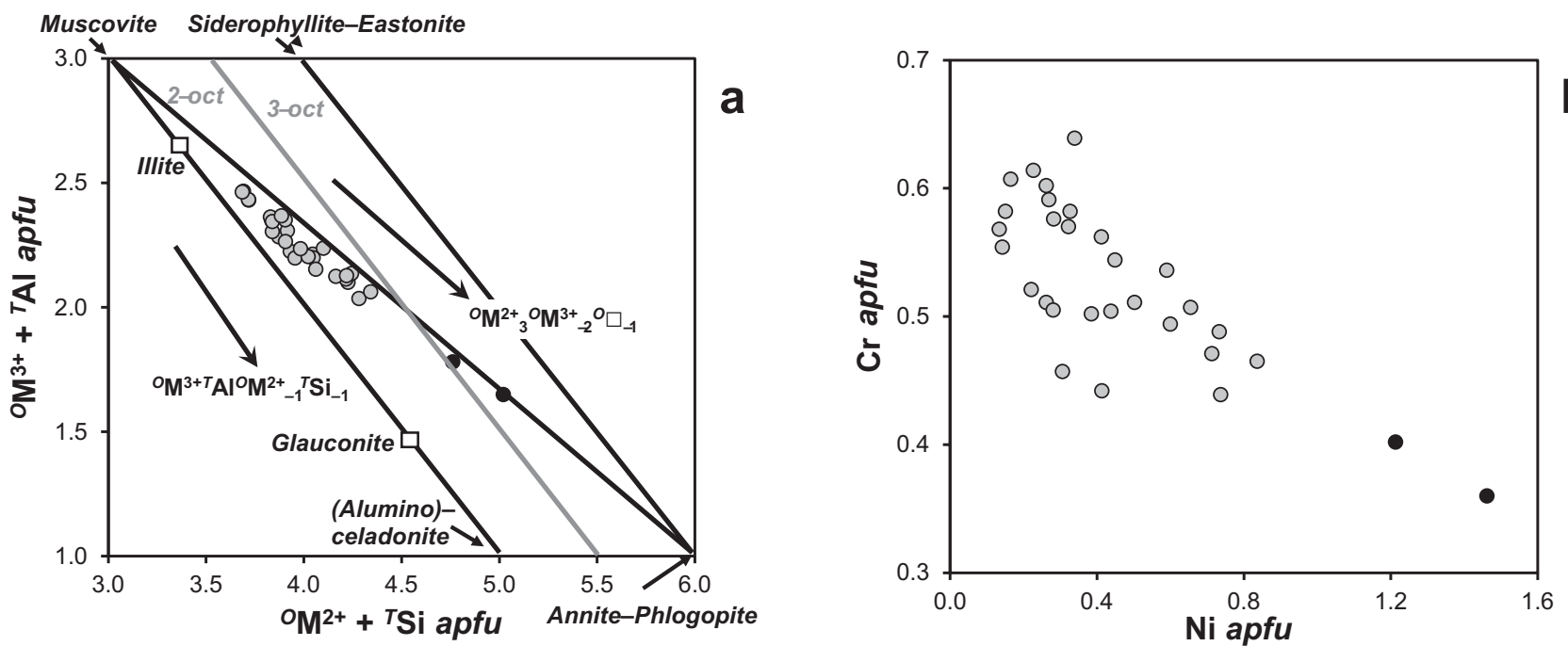

Fig. 4 Composition of $\mathrm{Cr}-\mathrm{Ni}$-rich illite to muscovite (grey circles) and Ni-dominant trioctahedral mica (black circles) from Muránska Zdychava listvenite $(a p f u) . \mathbf{a}-{ }^{o} \mathrm{M}^{2+}+{ }^{T} \mathrm{Si}$ vs. ${ }^{o} \mathrm{M}^{3+}+{ }^{T} \mathrm{Al}$ diagram showing two principal substitution mechanisms of the micas: $2^{\circ} \mathrm{M}^{3+}+{ }^{o} \square=3{ }^{o} \mathrm{M}^{2+}$ and ${ }^{o} \mathrm{M}^{3+}$ $+{ }^{T} \mathrm{Al}={ }^{O} \mathrm{M}^{2+}+{ }^{T} \mathrm{Si}$. Representative compositions of illite and glauconite (series names) are according to Rieder et al. (1998). The grey solid line indicates boundary between dioctahedral (2-oct) and trioctahedral (3-oct) micas. b - Ni vs. Cr substitution diagram (apfu). 
Tab. 4 Representative compositions of chromite from the Muránska Zdychava listvenite

\begin{tabular}{|c|c|c|c|c|c|c|c|c|}
\hline Anal. \# & 1 & 2 & 3 & 4 & 5 & 6 & 7 & 8 \\
\hline $\mathrm{TiO}_{2}$ & 0.23 & 0.18 & 0.07 & 0.00 & 0.07 & 0.11 & 0.16 & 0.09 \\
\hline $\mathrm{Al}_{2} \mathrm{O}_{3}$ & 0.40 & 0.81 & 3.87 & 4.06 & 4.45 & 1.78 & 0.85 & 11.85 \\
\hline $\mathrm{V}_{2} \mathrm{O}_{3}$ & 0.11 & 0.29 & 0.15 & 0.20 & 0.25 & 0.19 & 0.20 & 0.00 \\
\hline $\mathrm{Cr}_{2} \mathrm{O}_{3}$ & 56.95 & 57.18 & 59.62 & 61.37 & 62.55 & 62.66 & 58.78 & 49.87 \\
\hline $\mathrm{Fe}_{2} \mathrm{O}_{3} *$ & 11.16 & 10.71 & 5.31 & 3.23 & 1.87 & 4.76 & 9.45 & 4.61 \\
\hline $\mathrm{FeO}$ & 29.30 & 29.44 & 29.01 & 28.71 & 28.99 & 29.24 & 29.37 & 27.81 \\
\hline $\mathrm{ZnO}$ & 1.18 & 1.13 & 1.23 & 0.98 & 1.32 & 1.11 & 1.15 & 2.00 \\
\hline $\mathrm{MnO}$ & 0.62 & 0.54 & 0.50 & 0.46 & 0.45 & 0.54 & 0.61 & 0.25 \\
\hline $\mathrm{MgO}$ & 0.91 & 0.99 & 1.57 & 1.83 & 1.71 & 1.37 & 1.06 & 2.35 \\
\hline Total & 100.84 & 101.27 & 101.34 & 100.84 & 101.66 & 101.76 & 101.63 & 98.85 \\
\hline \multicolumn{9}{|c|}{ atomic proportions (on basis of $4 \mathrm{O}$ atoms) } \\
\hline $\mathrm{Ti}$ & 0.006 & 0.005 & 0.002 & 0.000 & 0.002 & 0.003 & 0.004 & 0.002 \\
\hline $\mathrm{A} 1$ & 0.017 & 0.035 & 0.163 & 0.171 & 0.186 & 0.076 & 0.036 & 0.491 \\
\hline $\mathrm{V}$ & 0.003 & 0.008 & 0.004 & 0.006 & 0.007 & 0.006 & 0.006 & 0.000 \\
\hline $\mathrm{Cr}$ & 1.660 & 1.655 & 1.688 & 1.739 & 1.756 & 1.786 & 1.693 & 1.385 \\
\hline $\mathrm{Fe}^{3+*}$ & 0.310 & 0.295 & 0.143 & 0.087 & 0.050 & 0.129 & 0.259 & 0.122 \\
\hline $\operatorname{Sum} B$ & 1.996 & 1.998 & 2.001 & 2.003 & 2.001 & 1.999 & 1.999 & 2.001 \\
\hline $\mathrm{Fe}^{2+}$ & 0.903 & 0.901 & 0.868 & 0.860 & 0.860 & 0.881 & 0.894 & 0.817 \\
\hline $\mathrm{Zn}$ & 0.032 & 0.031 & 0.033 & 0.026 & 0.035 & 0.029 & 0.031 & 0.052 \\
\hline $\mathrm{Mg}$ & 0.050 & 0.054 & 0.084 & 0.098 & 0.090 & 0.074 & 0.058 & 0.123 \\
\hline $\mathrm{Mn}$ & 0.019 & 0.017 & 0.015 & 0.014 & 0.014 & 0.017 & 0.019 & 0.007 \\
\hline Sum $A$ & 1.004 & 1.003 & 0.999 & 0.997 & 0.998 & 1.001 & 1.001 & 1.000 \\
\hline $\mathrm{O}$ & 4.000 & 4.000 & 4.000 & 4.000 & 4.000 & 4.000 & 4.000 & 4.000 \\
\hline
\end{tabular}

* calculated from stoichiometry

sulphide minerals occur mainly in the L1 and L2 types; they are less frequent in the L3 listvenite type.

Pyrite is the most widespread sulphide mineral of the listvenite; it forms usually anhedral, rarely subhedral crystals. The mineral shows elevated contents of nickel and cobalt: 0.7 to $5.1 \mathrm{wt} \% \% \mathrm{Ni}(\leq 0.10$ $a p f u)$ and 0.6 to 2.2 wt. \% Co $(\leq 0.05$ apfu). Nickel concentrations reveal slight negative correlation with $\mathrm{Fe}$ content $(\mathrm{r}=-0.67)$ but cobalt does not show any distinctive correlation with $\mathrm{Fe}$ or $\mathrm{Ni}(\mathrm{r}<-0.50)$. Two pyrite generations have been recognized: older pyrite I, generally with lower $\mathrm{Ni}$ or $\mathrm{Ni}$ + Co (1.8 to $3.1 \mathrm{wt}$ \% $\%$ ) and younger pyrite II that overgrows pyrite I (Fig. 6a), with higher $\mathrm{Ni}+\mathrm{Co}$ (4.2 to 5.8 wt. \%; Tab. 5).

Millerite is a relatively common mineral of the listvenite, forms discrete anhedral grains or veinlets in pyrite I. Locally, millerite occurs as trellis lamellae in a polydymiteviolarite series mineral, as a breakdown product of primary $\mathrm{Ni}-\mathrm{Co}-\mathrm{Fe}-\mathrm{S}$ solid-solution phase (Fig. 6b) or it is replaced by siegenite or gersdorffite (Fig. 6c). Millerite contains 0.6-4.2 wt. $\% \mathrm{Fe}(\leq 0.07$ apfu $)$, low concentrations of Co (max. 0.7 wt. \%) and negligible admixtures of $\mathrm{Pb}$ and $\mathrm{Cu}$ (Tab. 5). The millerite trellis lamellae in polydymiteviolarite show elevated contents of $\mathrm{Fe}+\mathrm{Co}$ (3.4-4.9 wt. $\%$ ) in comparison to discrete grains of millerite (Tab. 5). The most distinct $\mathrm{FeNi}_{-1}$ substitution in millerite displays very high negative correlation $(-0.98)$; relatively strong
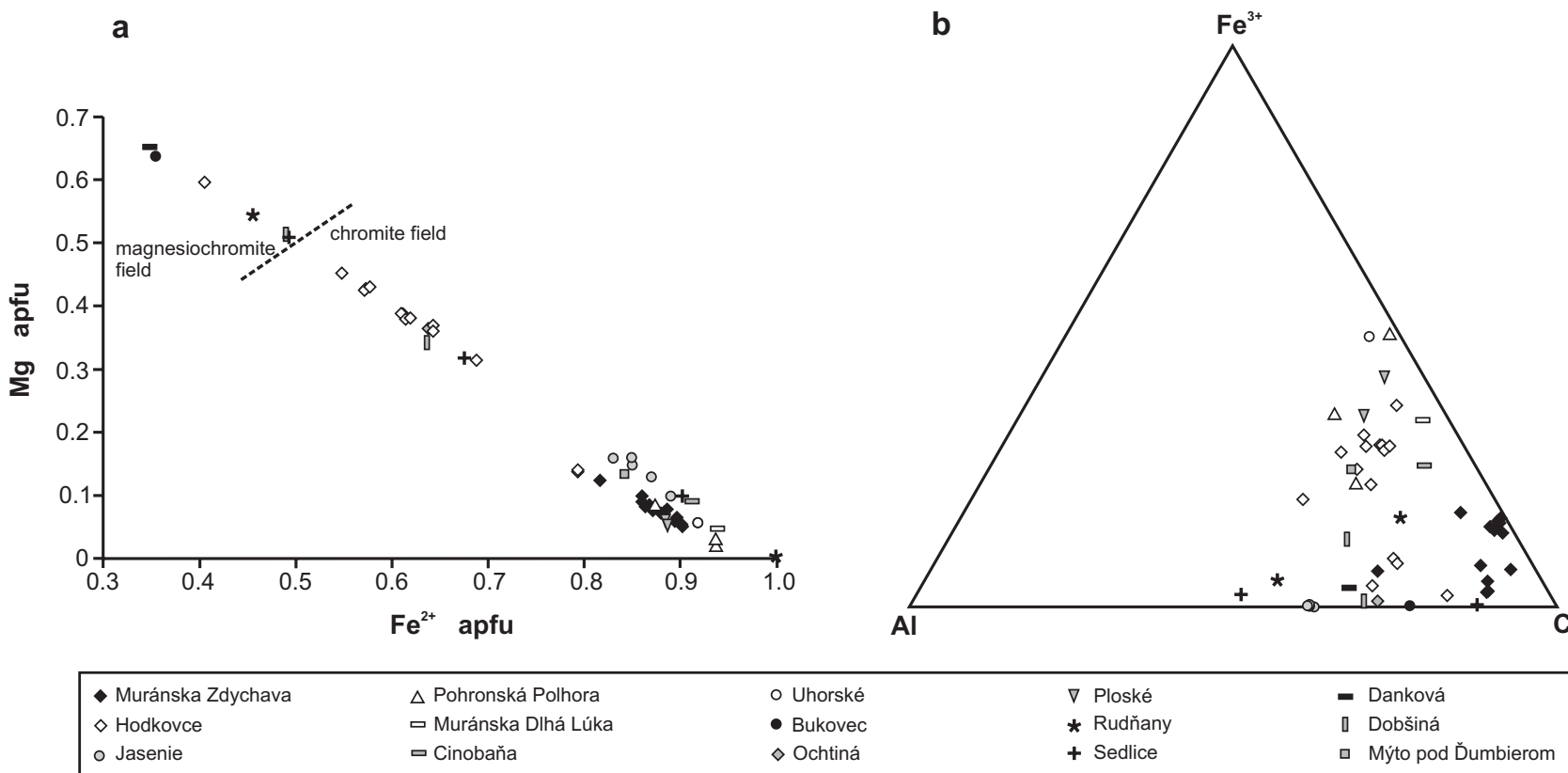

Fig. 5 Chromite compositions ( $a p f u$ ) from the Muránska Zdychava listvenite compared with Cr-rich spinels from other ultrabasic bodies in the Western Carpathians (Rojkovič 1985; Spišiak at al. 1994; Mikuš and Spišiak 2007). a - $\mathrm{Fe}^{2+}$ vs. $\mathrm{Mg}$ diagram. b $-\mathrm{Al}-\mathrm{Fe}^{3+}-\mathrm{Cr}$ diagram. 

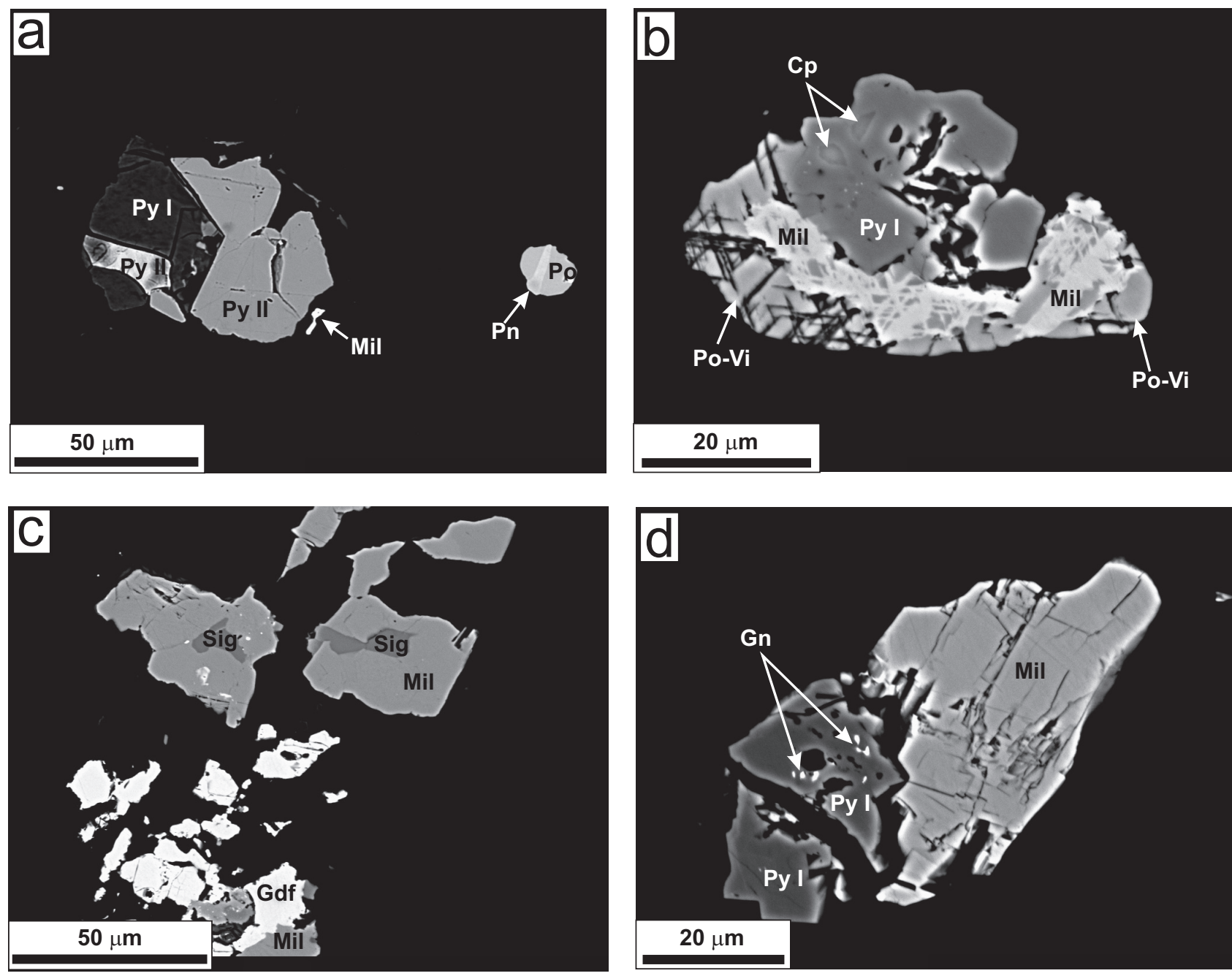

Fig. 6 Back-scattered electron images (BSE) of sulphide minerals in the Muránska Zdychava listvenite. a - Fractured pyrite I (Py I) overgrown by pyrite II (Py II). Millerite (Mil) forms small irregular grain at rim of pyrite aggregate, pentlandite lamella (Pn) occurs in isometric pyrrhotite grain (Po). b - Pyrite I (Py I) with chalcopyrite inclusions (Cp) is overgrown by millerite aggregate (Mil) and minerals of polydymite-violarite series (Po-Vi). Trellis-type lamellae of millerite in polydymite-violarite indicate exsolution breakdown of a primary solid solution. $\mathbf{c}-$ Millerite (Mil) is cut by siegenite veinlets (Sig), whereas gersdorffite (Gdf) replaces the both minerals. $\mathbf{d}$ - Pyrite I (Py I) containing galena inclusions (Gn) is associated with millerite (Mil).

correlations Co vs. Ni and Co vs. Fe $(-0.79$ and -0.78 , respectively) indicate $\mathrm{CoNi}_{-1}$ and $\mathrm{CoFe}_{-1}$ substitution mechanisms.

Thiospinel minerals of the polydymite-violarite series and siegenite were identified in the listvenite. The polydymite-violarite members overgrow pyrite I or they form discrete grains. The millerite lamellae in polydymite-violarite matrix (Fig. 6b) indicate the exsolution breakdown of primary $\mathrm{Ni}-\mathrm{Co}-\mathrm{Fe}-\mathrm{S}$ solid-solution phase. The mineral of the polydymite-violarite series reveals increased contents of Co (1.9 to 3.4 wt. \%, 0.10 to 0.17 apfu; Tab. 5, Fig. 7b). Excellent negative correlations between $\mathrm{Ni}$ and $\mathrm{Fe}$ or $\mathrm{Co}$ (up to -1.0) document the $\mathrm{FeNi}_{-1}$ and $\mathrm{CoNi}_{-1}$ substitution mechanisms.

Siegenite is the most common thiospinel mineral in the listvenite. It forms overgrowths or fracture fillings of discrete millerite grains (Fig. 6c). Siegenite shows high iron content (7.3 to 10.0 wt. \%, 0.40 to 0.55 apfu Fe; Tab. $5)$ and Fe partly substitutes Ni $(r=-0.84)$. Therefore, studied siegenite represents intermediate phase between siegenite end-member $\left(\mathrm{CoNi}_{2} \mathrm{~S}_{4}\right)$, violarite $\left(\mathrm{FeNi}_{2} \mathrm{~S}_{4}\right)$ and an unnamed $\mathrm{CoNiFeS}_{4}$ phase (Fig. 7b).

Gersdorffite occurs in local accumulations of discrete grains in association with millerite and thiospinels; in some cases it replaces millerite aggregates (Fig. 6c). Gersdorffite reveals wide variations in Co $(0.0$ to 11.7 wt. $\%, \leq 0.33 a p f u)$ and $\mathrm{Fe}(0.5$ to $2.2 \mathrm{wt}$. $\%, 0.02$ to 0.05 apfu); the content of $\mathrm{Sb}$ is negligible, max. 0.3 wt. \% (Tab. 5).

Cobaltite is a relatively rare mineral of the listvenite, it forms discrete anhedral crystals ( $\sim 15 \mu \mathrm{m}$ across) in magnesite I. It shows relatively high content of $\mathrm{Ni}(\sim 9$ wt. \%, 

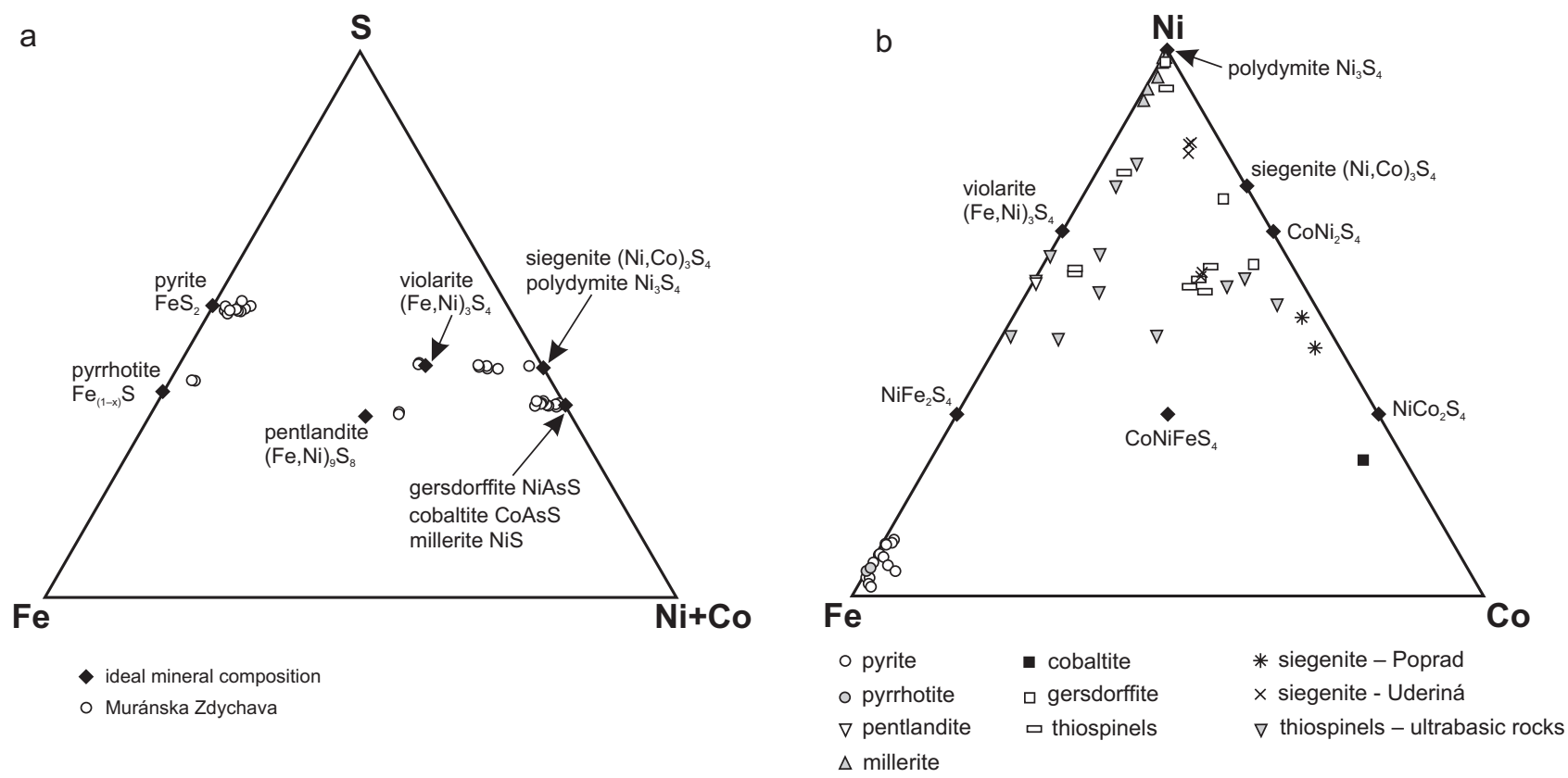

Fig. 7 Compositions of sulphide minerals (apfu) from Muránska Zdychava listvenite compared with those from the Alpine hydrothermal veins (Uderiná, Poprad) and other ultrabasic bodies in the Western Carpathians (Rojkovič 1985; Ferenc and Rojkovič 2001; Ferenc et al. 2014). $\mathbf{a}-\mathrm{Fe}-\mathrm{S}-\mathrm{Ni}+\mathrm{Co}$ diagram. $\mathbf{b}-\mathrm{Fe}-\mathrm{Ni}-\mathrm{Co}$ diagram.

$0.25 a p f u)$ and $\mathrm{Fe}(\sim 3$ wt. \%, $0.08 a p f u)$ (Tab. 5). Other uncommon sulphide minerals are pyrrhotite, pentlandite, chalcopyrite, and galena. Pyrrhotite forms tiny grains

scattered in magnesite I or intergrowths with pentlandite laths (Fig. 6a). Pyrrhotite contains 3.3 to 3.8 wt. \% Ni $(\sim 0.05$ apfu; Tab. 5). Chalcopyrite and galena were identified as minute inclusions $(2-5$ $\mu \mathrm{m})$ in pyrite I (Fig. 6b, d).

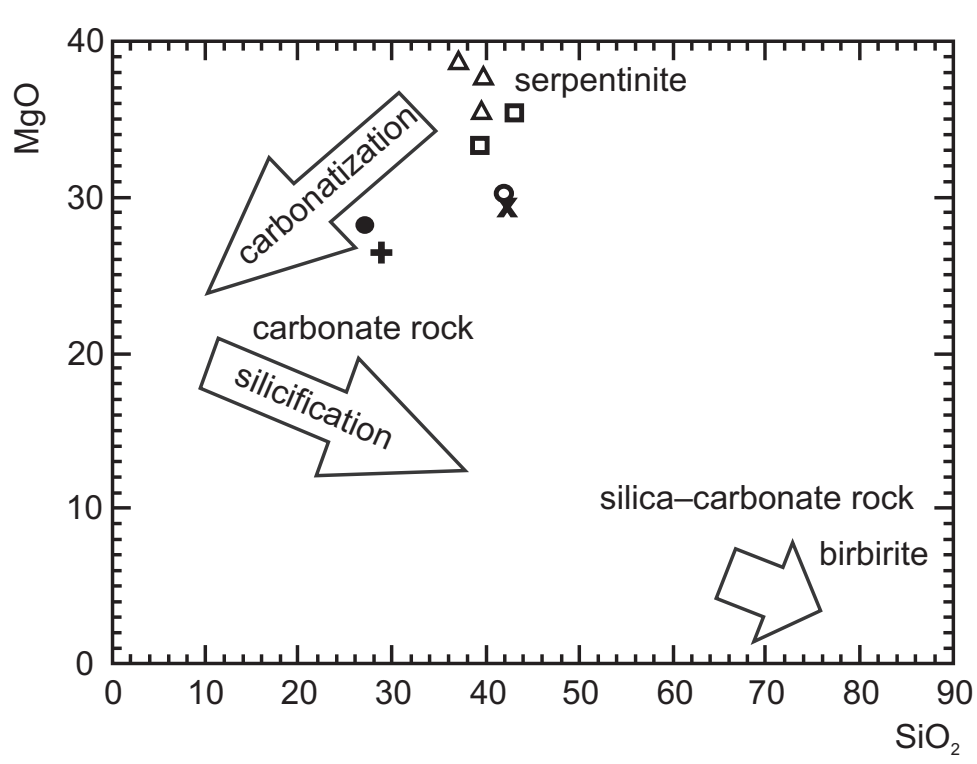

fluid condition

\subsection{Geochemical characterization of the listvenite}

Chemical composition of the L1 to L3 listvenite types (Tab. 6) shows high contents of $\mathrm{MgO}$ (26 to 30 wt. \%), $\mathrm{Fe}_{2} \mathrm{O}_{3}$ (6 to 7 wt. \%), $\mathrm{C}$ in carbonate form (5 to 10 wt. $\%), \mathrm{Cr}_{2} \mathrm{O}_{3}(\sim 0.3$ wt. $\%), \mathrm{NiO}(\sim 0.2$ wt. $\%)$, but very low contents of $\mathrm{SiO}_{2}$ (27 to 41 wt. \%), $\mathrm{Al}_{2} \mathrm{O}_{3}(\sim 0.5$ wt. \%), $\mathrm{Na}_{2} \mathrm{O}(<0.01$ wt. $\%)$ and $\mathrm{K}_{2} \mathrm{O}$ $(<0.15$ wt. \%); Ca content varies between 0.1 and 3.2 wt. $\%$ $\mathrm{CaO}$. The listvenite displays elevated concentrations of As and $\mathrm{Co}$, but contents of $\mathrm{Rb}$,

Fig. $8 \mathrm{SiO}_{2}$ vs. $\mathrm{MgO}$ binary diagram (wt. \%) showing chemical changes during alteration of serpentinites (according Akbulut et al. 2006). Explanations 1-5 represent analyses in Tab. 6 . 
Cr and Ni rich mineralization in listvenite, Veporic Superunit, Western Carpathians

$\mathrm{Sr}, \mathrm{Ba}$ and other trace elements (including REE) are very low (Tab. 6).

The listvenites at Muránska Zdychava provide a good example of a polystage transformation of the primary ultrabasic rock, as documented in the studied L1 to L3 rock types, which demonstrate various degrees of alteration (Tab. 6). The L3 type represents an incipient alteration stage with highest contents of $\mathrm{SiO}_{2}, \mathrm{MgO}$, and $\mathrm{Cr}_{2} \mathrm{O}_{3}$, typical of ultrabasic rocks (Fig. 8). The L1 and L2 types assume more advanced alteration with low $\mathrm{SiO}_{2}$ but with distinctly higher LOI (around 35 wt. \%), reflecting mainly $\mathrm{CO}_{2}$ and $\mathrm{H}_{2} \mathrm{O}$ in carbonates (magnesite and dolomite) and hydrated silicate minerals ( $\mathrm{Cr}-\mathrm{Ni}$-rich micas, serpentine group minerals and talc). On the contrary, all three listvenite types show very low contents of REE and other rare metals (e.g., Ga, Zr or U); concentrations of these trace elements were not distinctly influenced by alteration of primary ultrabasic rock (Tab. 6).

\section{Discussion}

The geochemistry and the alteration trends of the listvenites from Muránska Zdychava are generally comparable to the hydrothermal-metasomatic transformation in some other occurrences of listvenitized ultrabasic rocks (e.g., Hovorka et al. 1985; Akbulut et al. 2006; Styles et al. 2014; Figs 8-9). Ultrabasic or basic magmatic protolith (gabbros, basalts...) is essential for origin of the listvenites (e.g., Sazonov 1978; Dinel et al. 2008; Buckman and Ashley 2010). Two principal types of ultramafic rocks occur in the Western Carpathians (Hovorka
Tab. 5 Representative compositions of sulphide minerals from the Muránska Zdychava listvenite

\begin{tabular}{|c|c|c|c|c|c|c|c|c|c|c|}
\hline Anal. \# & $\mathrm{Fe}$ & Co & $\mathrm{Ni}$ & $\mathrm{Pb}$ & $\mathrm{Cu}$ & $\mathrm{Sb}$ & As & $\mathrm{S}$ & wt. $\%$ & Mineral \\
\hline 1 & 44.81 & 0.76 & 1.05 & 0.28 & & & & 52.82 & 99.72 & pyrite I \\
\hline 2 & 44.84 & 0.14 & 2.98 & 0.13 & & & & 52.28 & 100.37 & pyrite I \\
\hline 3 & 44.21 & 1.19 & 0.74 & 0.00 & & & & 52.97 & 99.11 & pyrite I \\
\hline 4 & 43.30 & 0.81 & 3.46 & 0.10 & & & & 52.56 & 100.24 & pyrite II \\
\hline 5 & 41.58 & 0.65 & 4.72 & 0.13 & & & & 52.53 & 99.62 & pyrite II \\
\hline 6 & 41.18 & 2.24 & 2.24 & 0.00 & & & & 53.49 & 99.16 & pyrite II \\
\hline 7 & 40.79 & 0.73 & 5.07 & 0.00 & & & & 53.32 & 99.91 & pyrite II \\
\hline 8 & 42.17 & 1.44 & 2.71 & 0.00 & & & & 53.17 & 99.50 & pyrite II \\
\hline 9 & 4.20 & 0.67 & 58.99 & 0.19 & 0.00 & & & 36.24 & 100.30 & millerite \\
\hline 10 & 3.45 & 0.36 & 59.92 & 0.15 & 0.07 & & & 35.84 & 99.79 & millerite \\
\hline 11 & 2.68 & 0.71 & 62.36 & 0.00 & 0.16 & & & 35.85 & 101.76 & millerite \\
\hline 12 & 0.62 & 0.18 & 63.43 & 0.14 & 0.00 & & & 35.19 & 99.56 & millerite \\
\hline 13 & 1.39 & 0.00 & 62.85 & 0.00 & 0.07 & & & 35.01 & 99.31 & millerite \\
\hline 14 & 19.13 & 3.36 & 33.57 & 0.21 & 0.06 & & 0.24 & 42.10 & 98.67 & violarite \\
\hline 15 & 10.18 & 2.62 & 44.96 & 0.00 & 0.06 & & 0.11 & 42.24 & 100.17 & violarite \\
\hline 16 & 2.15 & 1.93 & 52.85 & 0.00 & & & & 41.96 & 98.89 & polydymite \\
\hline 17 & 9.95 & 14.45 & 32.19 & 0.22 & & & & 41.87 & 98.68 & siegenite \\
\hline 18 & 8.91 & 16.12 & 31.71 & 0.19 & & & & 41.64 & 98.58 & siegenite \\
\hline 19 & 7.32 & 15.57 & 35.00 & 0.21 & & & & 41.84 & 99.94 & siegenite \\
\hline 20 & 1.69 & 8.00 & 25.67 & 0.07 & & 0.32 & 44.86 & 19.40 & 100.01 & gersdorffite \\
\hline 21 & 2.23 & 11.70 & 21.34 & 0.11 & & 0.29 & 44.22 & 19.40 & 99.30 & gersdorffite \\
\hline 22 & 0.55 & 0.03 & 35.76 & 0.00 & & 0.06 & 43.60 & 19.98 & 99.97 & gersdorffite \\
\hline 23 & 2.87 & 24.68 & 8.94 & 0.00 & & & 44.87 & 19.72 & 101.08 & cobaltite \\
\hline 24 & 55.00 & 0.02 & 3.30 & 0.22 & & & 0.09 & 38.53 & 97.16 & pyrrhotite \\
\hline 25 & 55.75 & 0.13 & 3.80 & 0.10 & & & 0.00 & 39.43 & 99.21 & pyrrhotite \\
\hline 26 & 26.27 & 0.13 & 38.02 & 0.22 & 0.00 & & & 33.05 & 97.69 & pentlandite \\
\hline 27 & 26.35 & 0.26 & 37.82 & 0.10 & 0.08 & & & 32.57 & 97.19 & pentlandite \\
\hline \multicolumn{11}{|c|}{ atomic proportions } \\
\hline 1 & 0.970 & 0.016 & 0.022 & 0.002 & & & & 1.991 & 3.000 & pyrite I \\
\hline 2 & 0.968 & 0.003 & 0.061 & 0.001 & & & & 1.967 & 3.000 & pyrite I \\
\hline 3 & 0.959 & 0.024 & 0.015 & 0.000 & & & & 2.001 & 3.000 & pyrite I \\
\hline 4 & 0.935 & 0.017 & 0.071 & 0.001 & & & & 1.977 & 3.000 & pyrite II \\
\hline 5 & 0.902 & 0.013 & 0.098 & 0.001 & & & & 1.986 & 3.000 & pyrite II \\
\hline 6 & 0.891 & 0.046 & 0.046 & 0.000 & & & & 2.017 & 3.000 & pyrite II \\
\hline 7 & 0.879 & 0.015 & 0.104 & 0.000 & & & & 2.002 & 3.000 & pyrite II \\
\hline 8 & 0.912 & 0.030 & 0.056 & 0.000 & & & & 2.003 & 3.000 & pyrite II \\
\hline 9 & 0.068 & 0.010 & 0.904 & 0.001 & 0.000 & & & 1.017 & 2.000 & millerite \\
\hline 10 & 0.056 & 0.006 & 0.925 & 0.001 & 0.001 & & & 1.012 & 2.000 & millerite \\
\hline 11 & 0.043 & 0.011 & 0.947 & 0.000 & 0.002 & & & 0.997 & 2.000 & millerite \\
\hline 12 & 0.010 & 0.003 & 0.986 & 0.001 & 0.000 & & & 1.001 & 2.000 & millerite \\
\hline 13 & 0.023 & 0.000 & 0.978 & 0.000 & 0.001 & & & 0.998 & 2.000 & millerite \\
\hline 14 & 1.047 & 0.174 & 1.749 & 0.003 & 0.003 & & 0.010 & 4.014 & 7.000 & violarite \\
\hline 15 & 0.552 & 0.135 & 2.319 & 0.000 & 0.003 & & 0.004 & 3.988 & 7.000 & violarite \\
\hline 16 & 0.118 & 0.101 & 2.764 & 0.000 & & & & 4.017 & 7.000 & polydymite \\
\hline 17 & 0.547 & 0.753 & 1.685 & 0.003 & & & & 4.012 & 7.000 & siegenite \\
\hline 18 & 0.491 & 0.842 & 1.664 & 0.003 & & & & 4.000 & 7.000 & siegenite \\
\hline 19 & 0.399 & 0.805 & 1.817 & 0.003 & & & & 3.976 & 7.000 & siegenite \\
\hline 20 & 0.050 & 0.225 & 0.725 & 0.001 & & 0.004 & 0.992 & 1.003 & 3.000 & gersdorffite \\
\hline 21 & 0.066 & 0.331 & 0.606 & 0.001 & & 0.004 & 0.984 & 1.008 & 3.000 & gersdorffite \\
\hline 22 & 0.016 & 0.001 & 1.002 & 0.000 & & & 0.957 & 1.025 & 3.000 & gersdorffite \\
\hline 23 & 0.084 & 0.684 & 0.249 & 0.000 & & & 0.978 & 1.005 & 3.000 & cobaltite \\
\hline 24 & 0.820 & 0.001 & 0.047 & 0.001 & & & 0.001 & 1.000 & 1.869 & pyrrhotite \\
\hline 25 & 0.812 & 0.005 & 0.053 & 0.000 & & & 0.000 & 1.000 & 1.870 & pyrrhotite \\
\hline 26 & 3.715 & 0.018 & 5.117 & 0.008 & 0.000 & & & 8.142 & 17.000 & pentlandite \\
\hline 27 & 3.752 & 0.035 & 5.123 & 0.004 & 0.010 & & & 8.076 & 17.000 & pentlandite \\
\hline
\end{tabular}

The crystallochemical formulae are calculated on the basis of 2 atoms (analyses 9-13), 3 atoms (1-8; 20-23), 7 atoms (15-19), 17 atoms (26-27), and $1 \mathrm{~S}$ atom (24-25) 
Tab. 6 Whole-rock chemical analyses of the Muránska Zdychava listvenite (L1 to L3 types)

\begin{tabular}{|c|c|c|c|c|c|c|}
\hline & L-1 & L-2 & L-3 & FMDL-35 & MDL-1 & MDL-2 \\
\hline $\mathrm{SiO}_{2}$ & 26.73 & 28.01 & 41.46 & 42.40 & 38.93 & 42.45 \\
\hline $\mathrm{TiO}_{2}$ & $<0.01$ & $<0.01$ & $<0.01$ & 0.02 & $<0.01$ & $<0.01$ \\
\hline $\mathrm{Al}_{2} \mathrm{O}_{3}$ & 0.52 & 0.51 & 0.55 & 1.41 & 3.31 & 3.88 \\
\hline $\mathrm{Fe}_{2} \mathrm{O}_{3 \text { tot }}$ & 6.76 & 6.44 & 6.13 & 8.05 & 7.90 & 6.60 \\
\hline $\mathrm{MgO}$ & 28.71 & 26.01 & 29.97 & 30.08 & 32.99 & 34.93 \\
\hline $\mathrm{CaO}$ & 0.44 & 3.22 & 0.07 & 0.43 & 2.72 & 0.54 \\
\hline $\mathrm{MnO}$ & 0.10 & 0.13 & 0.07 & 0.12 & 0.12 & 0.06 \\
\hline $\mathrm{Na}_{2} \mathrm{O}$ & $<0.01$ & $<0.01$ & $<0.01$ & 0.07 & 0.18 & 0.93 \\
\hline $\mathrm{K}_{2} \mathrm{O}$ & 0.14 & 0.14 & $<0.01$ & 0.07 & 0.10 & 0.33 \\
\hline $\mathrm{P}_{2} \mathrm{O}_{5}$ & $<0.01$ & 0.04 & $<0.01$ & 0.01 & 0.01 & $<0.01$ \\
\hline $\mathrm{Cr}_{2} \mathrm{O}_{3}$ & 0.276 & 0.263 & 0.361 & n.a. & n.a. & n.a. \\
\hline LOI & 35.60 & 34.60 & 20.60 & 17.72 & 13.62 & 11.02 \\
\hline Total & 99.28 & 99.36 & 99.21 & 100.38 & 99.88 & 100.74 \\
\hline $\mathrm{TOT} / \mathrm{C}$ & 10.00 & 9.80 & 4.61 & n.a. & n.a. & n.a. \\
\hline TOT/S & 0.03 & $<0.02$ & 0.03 & 0.12 & n.a. & n.a. \\
\hline $\mathrm{Cr}$ & & & & 1740 & 3050 & 3340 \\
\hline $\mathrm{Ni}$ & 1546 & 1408 & 1798 & 1235 & 1875 & 1503 \\
\hline $\mathrm{Co}$ & 89.1 & 76.4 & 87.8 & 54 & 110 & 124 \\
\hline $\mathrm{Cu}$ & 18.9 & 112.5 & 20.9 & 18 & n.a. & n.a. \\
\hline $\mathrm{Pb}$ & 3.8 & 24.2 & 1.6 & n.a. & n.a. & n.a. \\
\hline $\mathrm{Zn}$ & 49 & 62 & 35 & 101 & n.a. & n.a. \\
\hline $\mathrm{Sb}$ & 5.6 & 3.9 & 0.8 & n.a. & n.a. & n.a. \\
\hline $\mathrm{Bi}$ & 2.1 & 1.4 & 2.8 & n.a. & n.a. & n.a. \\
\hline As & 384.9 & 59.4 & 237.8 & n.a. & n.a. & n.a. \\
\hline $\mathrm{Rb}$ & 14.4 & 14.6 & 0.2 & n.a. & n.a. & n.a. \\
\hline Cs & 3.8 & 1.9 & 0.2 & n.a. & n.a. & n.a. \\
\hline $\mathrm{Sr}$ & 16 & 91.8 & 1.9 & n.a. & n.a. & n.a. \\
\hline $\mathrm{Ba}$ & 14 & 16 & 5 & n.a. & n.a. & n.a. \\
\hline $\mathrm{Ga}$ & 1.1 & 0.9 & 1.2 & n.a. & n.a. & n.a. \\
\hline $\mathrm{V}$ & 24 & 20 & 25 & 25 & 58 & 52 \\
\hline $\mathrm{U}$ & 0.1 & $<0.1$ & 0.2 & n.a. & n.a. & n.a. \\
\hline Sc & 6 & 5 & 6 & n.a. & 14 & 2 \\
\hline $\mathrm{Zr}$ & 1.4 & 0.1 & 0.2 & n.a. & n.a. & n.a. \\
\hline $\mathrm{Y}$ & 0.4 & 0.4 & 0.2 & n.a. & n.a. & n.a. \\
\hline $\mathrm{La}$ & 0.3 & $<0.1$ & 0.2 & n.a. & n.a. & n.a. \\
\hline $\mathrm{Ce}$ & 0.3 & $<0.1$ & 0.2 & n.a. & n.a. & n.a. \\
\hline Dy & $<0.05$ & $<0.05$ & 0.06 & n.a. & n.a. & n.a. \\
\hline $\mathrm{Yb}$ & 0.06 & $<0.05$ & $<0.05$ & n.a. & n.a. & n.a. \\
\hline $\mathrm{Au}$ & 2.8 & 8.7 & 2.1 & n.a. & n.a. & n.a. \\
\hline
\end{tabular}

$\mathrm{Fe}_{2} \mathrm{O}_{3}$ tot - total $\mathrm{Fe}$ as $\mathrm{Fe}_{2} \mathrm{O}_{3}$, n.a. - not analyzed.

oxides, $\mathrm{C}$ and $\mathrm{S}$ in wt. \%., trace elements in ppm and $\mathrm{Au}$ in $\mathrm{ppb}$

L 1-3 original analyses; FMDL-35- talc-carbonate rock, Muránska Dlhá Lúka (Ivan 1985); MDL-1 - antigorite serpentinite, MDL-2 - talc-antigorite serpentinite (Hovorka 1965)

1978): (1) basic to ultrabasic rocks of the gabbro-peridotite formation with characteristic $\mathrm{Fe}, \mathrm{Mn}$ and Ti enrichment and (2) ultrabasic rocks of the peridotite formation with elevated $\mathrm{Mg}, \mathrm{Cr}$ and $\mathrm{Ni}$ contents, and lower $\mathrm{Si}$ and alkalis compared with (1). Absence of ilmenite and presence of chromite as well as Ni-Co sulphide minerals (sensu Hovorka 1978; Rojkovič 1985) enable to assign the protolith of the Muránska Zdychava listvenite to the ultrabasic rocks of the peridotite formation.
The second principal prerequisite for the listvenite origin represent brittle tectonics and propagation of faults in the host rock, serving as channels for effective circulation of the mineralizing fluids (Hansen et al. 2005).

Moreover, listvenites are commonly associated with vein or metasomatic ore mineralizations, as for example in Ural Mts. (Sazonov 1975) or in the Rocky Mts. (Hansen et al. 2005). In the Western Carpathians, Cr-rich muscovite (fuchsite) and quartz-rich listvenites were described mainly from siderite-quartz-sulphide hydrothermal deposits (Dobšiná, Rudňany, Slovinky, Gelnica, Mlynky and other occurrences) of the Gemeric Superunit; rarely they occur in ultrabasic rocks at the Muránska Dlhá Lúka, Veporic Superunit and Jasenie in the Tatric Superunit (Ivan 1984, 1985; Grecula et al. 1995 and references therein).

Based on geochemical and mineralogical characteristics, the studied listvenite body near Muránska Zdychava originated during three principal evolution stages: (1) peridotite stage, (2) serpentinization stage, and (3) hydrothermal-metasomatic stage (listvenitization).

Rock-forming magmatic minerals of the primary ultrabasic rock, most probably peridotite (stage 1) were almost completely transformed to younger assemblages (2) and (3). However, relicts of Mg-bearing chromite, rare pyrrhotite with pentlandite lamellae and pyrite I with chalcopyrite exsolutions are still preserved.

The serpentinization stage (2) is represented by serpentine minerals (with later magnesite I + quartz assemblage) is partly preserved mainly in the L3 type of the listvenite (Tab. 6, Fig. 8). Moreover, we suggest a partial dissolution of the older sulphide minerals, mobilization of Ni, Co, Fe, S, As and their new precipitation in the form of pyrite II + millerite + siegenite + polydymite + violarite + gersdorffite + cobaltite mineral assemblage during serpentinization. The secondary origin of sulphide and sulphoarsenide minerals due to serpentinization is generally a characteristic feature of ultramafic bodies in the Western Carpathians (Rojkovič 1985). Precipitation of $\mathrm{Ni}$ and Co sulphoarsenides is typical of advanced serpentinization to listvenitization, and this process can be an effective for $\mathrm{Ni}$ and $\mathrm{Co}$ mobilization and accumulation, perhaps up to economic concentrations, such as in the Dobšiná deposit, Slovakia 
Fig. 9 Ternary diagram $\mathrm{Fe}_{2} \mathrm{O}_{3}-\mathrm{SiO}_{2}-$ $\mathrm{MgO}+\mathrm{CaO}$ with alteration trends of serpentinites and fields of altered rocks according to Akbulut et al. (2006). Explanations 1-5 represent analyses in Tab. 6.

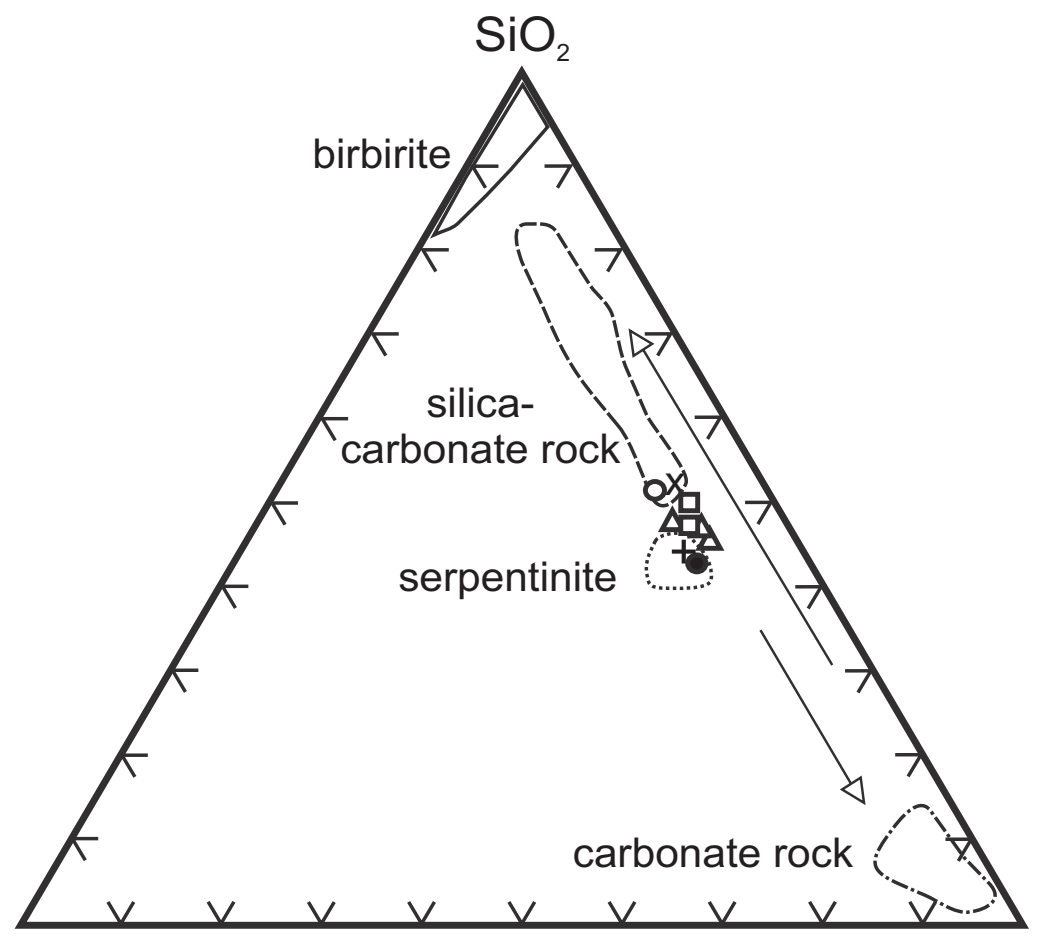

$\mathrm{Fe}_{2} \mathrm{O}_{3}$

$\mathrm{CaO}+\mathrm{MgO}$

- 1 Muránska Zdychava listvenite (L1)

+ 2 Muránska Zdychava listvenite (L2)

X 3 Muránska Zdychava listvenite (L3)

- 4 Talc-carbonate rock, Muránska DIhá Lúka (FMDL-35, Ivan 1985)

口 5 Antigorite-talc serpentinite, Muránska Dlhá Lúka (MDL-1, 2, Hovorka 1965)

$\Delta 6$ Various serpentinites (Styles et al. 2014)
(Ivan and Hovorka 1980), Kamaishi mining district, Japan (Shiga 1987) or Bou Azzer deposit, Morocco (Alansari et al. 2015). Millerite and polydymite were observed also in steatitized abyssal peridotites of the Mid-Atlantic Ridge, where increased Si and decreased $\mathrm{H}_{2}$ activities enable precipitation of high sulphur-fugacity sulphides (Klein and Bach 2009).

The third, advanced hydrothermal-metasomatic stage (listvenitization) represent mainly the L1 and L2 types of the listvenite with dominant magnesite I-II + dolomite $\mathrm{I}-\mathrm{II}+$ quartz $+\mathrm{Cr}-\mathrm{Ni}$-rich micas. This alteration of serpentinized rocks by $\mathrm{CO}_{2}$-rich fluids is illustrated by the following reaction: $\mathrm{Mg}_{3} \mathrm{Si}_{2} \mathrm{O}_{5}(\mathrm{OH})_{4}+3 \mathrm{CO}_{2}=$ $3 \mathrm{MgCO}_{3}+2 \mathrm{SiO}_{2}+2 \mathrm{H}_{2} \mathrm{O}$ (Halls and Zhao 1995). Generally, alteration of ultrabasic rocks to listvenites involves two basic processes (Akbulut et al. 2006; Figs 8-9). (1) Silicification is caused by fluids rich in $\mathrm{SiO}_{2}$ and $\mathrm{H}_{2} \mathrm{O}$ at relatively low $\mathrm{pH}$. This process leads to quartz \pm carbonate rocks with unusually high $\mathrm{SiO}_{2}$ contents, up to 80 wt. \% (birbirites). (2) Carbonatization represents the alteration by fluids enriched in $\mathrm{CO}_{2}, \mathrm{H}_{2} \mathrm{O}$ and $\mathrm{Ca}^{2+}$, with higher $\mathrm{pH}$, as well as decreased $\mathrm{fS}_{2}$ and $f \mathrm{O}_{2}$ in comparison with the silicification. The altered ultrabasic rocks reveal low $\mathrm{SiO}_{2}$ but high $\mathrm{CaO}$ and $\mathrm{MgO}$ contents. In our case, the final hydrothermal-metasomatic transformation of the Muránska Zdychava listvenite included relatively rapid decrease in $\mathrm{SiO}_{2}$, slight decrease in $\mathrm{MgO}$ and only insignificant increase in $\mathrm{K}_{2} \mathrm{O}$. Strong enrichment of total carbon in L1-L2 analyses (Tab. 6) is unambiguously a manifestation of high $\mathrm{CO}_{2}$ content in fluids responsible for the listvenitization.

The $\mathrm{Cr}-\mathrm{Ni}$-rich micas precipitated during the listvenitization of the investigated ultrabasic rock, in association with magnesite, dolomite and quartz (Fig. 2a, c). The micas from the Muránska Zdychava listvenite contain the highest values of $\mathrm{Ni}$ ever reported in the mica-group minerals (up to 22.8 wt. $\% \mathrm{NiO}$ or 1.46 apfu $\mathrm{Ni}$ ); the $\mathrm{Cr}$ concentrations are also relatively high (up to 11.0 wt. $\% \mathrm{Cr}_{2} \mathrm{O}_{3}$ or $0.64 a p f u$ ). The micas were formed under a significant $\mathrm{Al}$ and $\mathrm{K}$ deficit (Tab. 6), 
which caused their small volume in listvenite and unusual composition.

Similar micas with unusually high $\mathrm{Cr}$ and $\mathrm{Ni}$ contents were formed under analogous conditions in transformed ultrabasic rocks. The maximum $\mathrm{Ni}$ content in previously reported chromian muscovite attained $8.75 \mathrm{wt}$ \% $\mathrm{NiO}(0.53$ apfu $)$, together with up to 13.5 wt. $\% \mathrm{Cr}_{2} \mathrm{O}_{3}$ (0.75 apfu); it occurs in quartz veins and stockworks that traverse the ophiolitic emerald-hosting, carbonatealtered ultramafic rocks in the Swat Valley, the Indus suture, NW Pakistan (Arif and Moon 2007). Nickel-rich phlogopite (up to 4.3 wt. \% $\mathrm{NiO}$ or $0.26 \mathrm{apfu}$ ) occurs in association with Ni-bearing sodium amphibole, chlorite and talc in Ni-rich lateritic rocks transformed from serpentinites in Studena Voda Fe-Ni ore deposit of the Vardar ophiolite zone in Macedonia (Maksimović and Pantó 1982). Muscovite with 5.5 wt. $\% \mathrm{Cr}_{2} \mathrm{O}_{3}$ and 2.0 wt. \% $\mathrm{NiO}(0.29$ apfu $\mathrm{Cr}$ and 0.11 apfu $\mathrm{Ni}$ ) was described from quartz-magnesite listvenites with chromite in the Setogawa Group, east of Nagoya, Japan (Takasawa et al. 1976). Despite the lack of textural evidence, we assume partly dissolved chromite as a main source of $\mathrm{Cr}$. Similarly, primary Ni-bearing silicate minerals (especially serpentinized olivine?) or older Ni-rich sulphide minerals (probably pentlandite) could have served as a principal source of $\mathrm{Ni}$ in the micas. Analogous partial dissolution and replacement of primary chromite by $\mathrm{Cr}-\mathrm{Ni}$-rich muscovite was documented in listvenitized ultrabasic rock from Swat Valley, Pakistan (Arif and Moon 2007).

The listvenitization of ultrabasic rocks represents a hydrothermal-metasomatic process under the greenschist-facies metamorphic conditions, at $\sim 290$ to $340{ }^{\circ} \mathrm{C}$ and $\sim 100$ to $300 \mathrm{MPa}$ (eg., Halls and Zhao 1995; Plissart et al. 2009; Bagherzadeh et al. 2013). In the studied listvenite body near Muránska Zdychava, this process was probably connected with Alpine (Late Cretaceous), late-orogenic uplift of the Veporic Superunit crystalline basement and retrograde metamorphism at temperature of 350 to $500^{\circ} \mathrm{C}$ and pressure of 200 to 400 MPa (Kováčik et al. 1996). Consequently, we assume that the final listvenite stage took place at $\sim 200 \mathrm{MPa}$ and less than $350^{\circ} \mathrm{C}$. These conditions corresponded to en-block exhumation of Veporic Superunit between 80 and $55 \mathrm{Ma}$, resulting from the underthrusting of the Tatric-Fatric continental crust from the north. In this time period, central part of the Veporic Superunit cooled down from $350^{\circ} \mathrm{C}$ to $60^{\circ} \mathrm{C}$ (Vojtko et al. 2016). The NE-SW and NW-SE trending fault structures played a key role during the listvenitization; they presumably channelled the $\mathrm{CO}_{2}$-rich fluids that transformed the serpentinized peridotite into magnesite I + dolomite I + quartz + Cr-Ni-rich muscovite. Contemporaneously with the listvenite origin, some hydrothermal siderite and quartz-sulphide mineralizations grew on the fault zones of metamorphic rocks in the Muránska Zdychava area (Mat'o et al. 2005). The Late Cretaceous age ( 70 to $80 \mathrm{Ma}$ ) and presence of $\mathrm{CO}_{2}$-rich fluids was documented for analogous hydrothermal mineralization in adjacent Gemeric Superunit of the Western Carpathians (Hurai et al. 2008). The youngest mineralization of the studied listvenite (younger hydrothermal, sensu Hovorka et al. 1985) is represented by veinlets of white calcite without sulphide minerals.

\section{Conclusions}

1) The listvenite near Muránska Zdychava originated from primary magmatic ultrabasic body (probably peridotite) during three principal evolution stages: (1) magmatic stage, (2) serpentinization stage, and (3) hydrothermal-metasomatic stage (listvenitization).

2) The final listvenitization stage (3) took place during Alpine (Late Cretaceous) late-orogenic uplift and retrograde metamorphism of the Veporic Superunit crystalline basement; its assumed $\mathrm{P}-\mathrm{T}$ conditions were $\sim 200 \mathrm{MPa}$ and $\leq 350^{\circ} \mathrm{C}$.

3) The NE-SW and NW-SE trending fault structures likely played a key role during the listvenitization, as they provided channels for circulation of $\mathrm{CO}_{2}$-rich fluids that transformed the serpentinized peridotite into carbonate-quartz-rich listvenite.

4) The micas from the Muránska Zdychava listvenite represent $\mathrm{Cr}-\mathrm{Ni}$-rich illite to muscovite and $\mathrm{Ni}$-dominant trioctahedral mica (probably a new, formally unapproved mineral species). They contain the highest values of Ni ever reported in the mica-group minerals (up to 22.8 wt. \% NiO; or 1.46 apfu $\mathrm{Ni}$ ), the $\mathrm{Cr}$ concentrations attain 11.0 wt. $\% \mathrm{Cr}_{2} \mathrm{O}_{3}(0.64$ apfu). Chromium shows negative correlation with $\mathrm{Ni}$; two principal substitution mechanisms occur in the micas: $2^{O} \mathrm{M}^{3+}+{ }^{O} \square=3{ }^{O} \mathrm{M}^{2+}$ and ${ }^{O} \mathrm{M}^{3+}+{ }^{T} \mathrm{Al}={ }^{O} \mathrm{M}^{2+}+{ }^{T} \mathrm{Si}$.

5) Chromite and $\mathrm{Ni}-\mathrm{Co}-\mathrm{Fe}$ sulphide minerals (mainly pentlandite, millerite, polydymite, violarite, siegenite and gersdorffite) were the main sources for the formation of $\mathrm{Cr}-\mathrm{Ni}$-rich micas during the final hydrothermal-metasomatic stage of the listvenite formation, together with their intense carbonatization.

Acknowledgements. This work was supported by the Slovak Research and Development Agency projects APVV0081-10 and APVV-15-0050, as well as the Ministry of Education, Slovak Republic (VEGA-1/0255/11 and VEGA-1/0650/15). Authors thank V. Kollárová for her assistance during the electron-microprobe work and both reviewers, L. Ackerman and P. Ivan, for their valuable comments that improved the manuscript. 


\section{References}

Akbulut M, PişKin Ö, KaraYiĞIT AI (2006) The genesis of the carbonatized and silicified ultramafics known as listvenites: a case study from the Mihaliççik region (Eskişehir), NW Turkey. Geol J 41: 557-580

Alansari A, Bhilisse M, Maacha L, Soulaimani A, Michard A, Ennaciri A (2015) The Co, Ni, Cr and S mineralisation during serpentinization process in the Bou Azzer ore deposits (Anti-Atlas, Morocco). J Tethys 3: 216-236

Arif M, Moon CJ (2007) Nickel-rich chromian muscovite from the Indus suture ophiolite, NW Pakistan: implications for emerald genesis and exploration. Geochem J 41: 475-482

Bagherzadeh RM, Mirnejad H, Eshback P, Karimpour MH (2013) Investigation of Au-bearing listvenite using mineralogy, geochemistry, fluid inclusion and stable isotopes (oxygens, carbon and sulphur) in ophiolite-melange zone of East Iran, Hangaran area, South Birjand. Scient Quart J Geosci 22: 131-144

BEZÁK V (1982) Metamorphic and granitic complexes in the Kohút Belt of Veporic Unit. Geol Práce, Správy 78: 65-70 (in Slovak)

BezÁK V, HrašKo L', KoneČnÝ V, KováčIK M, Madarás J, Plašienka D, Pristaš J (1999) Geological map of the Slovenské Rudohorie Mts. - western part, 1 : 50000. State Geological Institute of D. Štúr, Bratislava (in Slovak)

Buckman S, Ashley PM (2010) Silica-carbonate (listwanites) related gold mineralisation associated with epithermal alteration of serpentinite bodies. In: BuCKMAN S, BlEvin PL (eds) New England Orogen 2010. University of New England, Armidale, NSW, Australia, pp 94-105

Dinel E, Fowler AD, Ayer J, Still A, Tylee K, Barr E (2008) Lithogeochemical and stratigraphic controls on gold mineralization within the metavolcanic rocks of the Hoyle Pond Mine, Timmins. Econ Geol 103: 1341-1363

FERENC Š, RoJkovič I (2001) Copper mineralization in the Permian basalts of the Hronicum Unit, Slovakia. Geolines 13: 22-27

Ferenc Š, Bakos F, Demko R, Koděra P (2014) Occurrences of siderite (Fe-carbonate) and quartz-sulphide mineralization near Lovinobaňa and Uderiná (Slovenské Rudohorie - Veporikum), Slovak Republic. Bull mineral.-petrolog Odd Nár Muz (Praha) 22: 25-41 (in Slovak)

García DR, Villanova-de-Benavent C, Butjosa L, Aiglsperger T, Melgarejo J C, Proenza JA, IturraldeVincent M, Garcia-CAsco A (2015) Au mineralization in "listvenites" from Mina Descanso, Central Cuba: preliminary results. In: AndrÉ-MeYer AS, CATHELINEAu M, Muchez P, Pirard E, Sindern S (eds) Mineral Resources in a Sustainable World. Vol. 1, Contributions from the $13^{\text {th }}$ Biennial Meeting of the Society for Geology Applied to Mineral Deposits (SGA), 08/2015, Nancy (France), 197-200

Grecula P, Abonyi A, Abonyiová M, Antaš J, Bartalský B, Bartalský J, DianišKa I, DrnzíK E, Ďuňa R, GarguLÁK M, GAZdaČKo L, HudÁČEK J, KoBUlskÝ J, LÖRINZ L, Macko J, NÁvesňÁk D, Németh Z, Novotný L, Radvanec M, Rojkovič I, RozložNík L, RozložNík O, VARČEK C, Zlocha J (1995) Mineral raw deposits of Slovenské Rudohorie Mts., Vol. 1. Mineralia Slovaca Monograph, Bratislava, pp 1-834 (in Slovak)

Halls C, ZHAO R (1995) Listvenite and related rocks: pespectives on terminology and mineralogy with reference to an occurrence at Cregganbaur, Mayo Co., Republic of Ireland. Miner Depos 30: 303-313

Hansen LD, Dipple GM, Gordon TM, Kellet DA (2005) Carbonated serpentinite (listwanite) at Atlin, British Columbia: a geological analogue to carbon dioxide sequestration. Canad Mineral 43: 225-239

Hovorka D (1965) Serpentinites of the Kohút Crystalline Complex and their metamorphic products. Acta Geol Geogr Univ Com, Geol 9: 91-140 (in Slovak)

Hovorka D (1978) Geochemistry of the West Carpathians Alpine-type Ultramafic Rocks. Náuka o Zemi, Geol 12. Veda, Bratislava, pp 1-153

Hovorka D, Ivan P, Jaroš J, Kratochvíl M, Reichwalder P, RoJkovič I, SPIŠIAK J, Turanová L (1985) Ultramafic Rocks of the Western Carpathians, Czechoslovakia. Geological Institute of D. Štúr Press, Bratislava, pp $1-258$

HrašKo L', Bakos F, Broska I, Demko R, Derco J, Ferenc Š, Fodorová V, KovÁčIK M, Král J, Madarás J, Maglay J, Maťo L', Nagy A, Németh Z, Putiš M, Radvanec M, SiMAN P, Šimon L, Tuček L, VozÁrovÁ A, Zuberec J (2005) Assessment of Geological and Raw-Material Potential of the Slovenské Rudohorie - West Area and Possibilities of their Utilization for the Region Development. Unpublished report, State Geological Institute of D. Štúr, Bratislava, pp 1-139 (in Slovak)

Hurai V, Lexa O, Schulmann K, Montigny R, Prochaska W, Frank W, Konečný P, Král J, Thomas R, Chovan M (2008) Mobilization of ore fluids during Alpine metamorphism: evidence from hydrothermal veins in the Variscan basement of Western Carpathians, Slovakia. Geofluids 8: 181-207

Ivan P (1984) Metasomatites (listvenites) replacing ultrabasics (Paleozoic, Inner Western Carpathians). Miner Slov 16: 103-114

IvAN P (1985) Hydrothermally-metasomatic alterations of ultrabasic rocks. In: HovorkA D (ed) Ultramafic Rocks of Western Carpathians, Czechoslovakia. Geological Institute of D. Štúr Press, Bratislava, pp 171-180

Ivan P, Hovorka D (1980) Co-Ni mineralization at Spišskogemerské Rudohorie Mts., suggestions for search. Geol Průzk 22: 225-228 (in Slovak) 
Klein F, BACH W (2009) Fe-Ni-Co-O-S phase relations in peridotite-seawater interactions. J Petrol 50: 39-59

KLineC A (1976) Geological map of the Slovenské Rudohorie and Nízke Tatry Mountains, 1: 50 000. Geological Institute of D. Štúr, Bratislava

KováČIK M, KRÁL J, Maluski H (1996) Alpine metamorphic and thermochronological evolution of pre-Alpine metamorphic rocks in the South Veporic pre-Alpine metamorphic rocks. Miner Slov 28: 185-202 (in Slovak)

Maksimović Z, Pantó G (1982) Nickel-bearing phlogopite from the nickel-iron deposit Studena Voda (Macedonia). Bull Acad Serbe Sci Arts 80: 1-6

Maťo L', Ferenc Š, Bakos F, Demko R, KrÁl J (2005) Ore Mineral Raw Materials of the Slovenské Rudohorie West Area. In: HrAšKo L' (ed) Assessment of Geological and Raw-Material Potential of the Slovenské Rudohorie - West Area and Possibilities of their Utilization for the Region Development. Unpublished report, Geological Institute of D. Štúr, Bratislava, pp 1-317 (in Slovak)

Mikuš T, Spišıak J (2007) Chemical composition and alteration of Cr-spinels from Meliata and Penninic serpentinized peridotites (Western Carpathians and Eastern Alps). Geol Q 51: 257-270

Plašienka D, Grecula P, Putiš M, Hovorka D, Kováč M (1997) Evolution and structure of the Western Carpathians: an overview. In: Grecula P, Hovorka D, Putiš M (eds) Geological Evolution of the Western Carpathians. Mineralia Slovaca Monograph, Geocomplex and Geological Survey of Slovak Republic, Bratislava, pp 1-24

Plissart G, Féménias O, Maruntiu M, Diot H, Demaiffe D (2009) Mineralogy and geothermometry of gabbroderived listvenites in the Tisovita-Iuti ophiolite, southwestern Romania. Canad Mineral 47: 81-105

Pouchou JL, Pichoir F (1985) "PAP” ( $\varphi \rho Z)$ procedure for improved quantitative microanalysis. In: ARMSTRONG JT (ed) Microbeam Analysis. San Francisco Press, San Francisco, pp 104-106

Rieder M, Cavazzini G, D'yakonov YS, Frank-Kamenetski VA, Gottardi G, Guggenheim S, Koval PV, Müller G, Neiva AMR, Radoslovich EW, Robert JL, Sassi FP, Takeda H, Weiss Z, Wones DR (1998) Nomenclature of the micas. Clay Clay Miner 46: 586-595

RoJKOVIČ I (1985) Ore mineralization of ultramafic bodies of the Western Carpathians. Veda, Bratislava, pp 1-112 (in Slovak)

SAzonov VN (1975) Listvenitization and Ore Mineralization. Nauka, Moscow, pp 1-171 (in Russian)
Sazonov VN (1978) Chromium in Hydrothermal Process (on Example of the Ural Mts.). Nauka, Moscow, pp 1-286 (in Russian)

SHIGA Y (1987) Behavior of iron, nickel, cobalt and sulfur during serpentinization, with reference to the Hayachine ultrabasic rocks of the Kamaishi mining district, northeastern Japan. Canad Mineral 25: 611-624

Simic V, Saric K, Miladinovic Z, Andric N, Vukovic N (2013) Listvenite from Serbia as gemstone resource. In: Schuster R (ed) $11^{\text {th }}$ Workshop on Alpine Geological Studies \& $7^{\text {th }}$ European Symposium on Fossil Algae. Abstracts and Field Guides, 09/2013, Schladming. Berichte Geol B-A 99: 86

Slavkay M, BeňKa J, BezÁk V, Gargulák M, HrašKo L', KováčiK M, Petro M, VozÁrová A, HrušKoviČ S, KNÉSL J, Knéslová A, Kusein M, MaŤová V, Tulis J (2004) Mineral deposits of the Slovenské Rudohorie Mts., Vol. 2. State Geological Institute of Dionýz Štúr, Bratislava, pp 1-286 (in Slovak)

SPIŠIAK J, PITOŇÁK P, CAŇO F (1994) Allanite and Al-chromite in corundum-phlogopite rocks from Jasenie-Kyslá area (Nízke Tatry Mountains). Miner Slov 26: 67-69 (in Slovak)

Styles MT, Sanna A, Lacinska AM, Naden J, MarotoVALER M (2014) The variation in composition of ultramafic rocks and the effect on their suitability for carbon dioxide sequestration by mineralization following acid leaching. Greenhouse Gas Sci Technol 4, 440-451

Takasawa K, Sakae T, TAKeyama H (1976) Nickeliferous fuchsite un the quartz-magnesite rocks from the Setogawa Group, Japan. Clay Sci 5: 57-65

Uher P, Ferenc Š, Spišiak J (2013) Cr-Ni muscovite from Muránska Zdychava near Revúca (Slovenské Rudohorie Mountains, central Slovakia). Bull mineralpetrolog Odd Nár Muz (Praha) 21: 62-66 (in Slovak)

Vass D, Began A, Gross P, Kahan Š, Köhler E, Lexa J, NEMČOK J (1988) Regional geological classification of the Western Carpathians and northern offshoots of Pannonian Basin in Czechoslovakia area. Map, 1:500 000 scale. Slovak Geological Office and Geological Institute of D. Štúr, Bratislava

VojtKo R, KrÁliková S, JeřÁBek P, Schuster R, DANišík M, Fügenschuch B, MinÁr J, MadArÁs J (2016) Geochronological evidence for Alpine tectono-thermal evolution of the Veporic Unit (Western Carpathians, Slovakia). Tectonophysics 666: 48-65 